\title{
Big fish in small banking ponds? Cost advantage and foreign affiliate presence ${ }^{\text {is }}$
}

\author{
R. Galema, M. Koetter* \\ Utrecht University, School of Economics, P.O. Box 80125, 3508 TC Utrecht, Netherlands \\ Deutsche Bundesbank, Wilhelm-Epsteinstraße 14, 60431 Frankfurt a.M., Germany \\ Halle Institute for Economic Research (IWH) and Otto-von-Guericke University, Kleine Märkerstraße 8, 06108 Halle (Saale), Germany
}

\section{A R T I C L E I N F O}

\section{Article history:}

Available online 22 November 2017

\section{JEL classification:}

F3

G21

Keywords:

Multinational banks

Cost advantage

International banking

\begin{abstract}
A B S T R A C T
We distinguish cost advantage at home from cost advantage vis-à-vis incumbent banks in destination markets to explain the probability of foreign bank affiliate lending. We combine detailed affiliate lending data of all German banks with public bank micro data from 59 destination markets. The likelihood to operate foreign affiliates depends positively on both types of cost advantage. Only cost advantage at home is economically significant. Generally, risk, return, and unobservable bank traits explain a larger share of the variation in foreign affiliate operations. Less profitable, more risky, and larger banks are more likely to operate affiliates abroad.
\end{abstract}

(c) 2017 Elsevier Ltd. All rights reserved.

\section{Introduction}

Do cost advantages determine foreign direct investment (FDI) in banking? We investigate the role played by the efficiency of banks in the home country and in the efficiency of its competitors in potential host countries. We assess efficiency differences in terms of cost advantage, i.e. banks having lower costs than their competitors, and distinguish two types of cost advantages: a cost advantage of banks compared to competitors at home and a cost advantage compared to competitors abroad. We empirically identify these two different types of cost advantage and quantify their economic significance relative to other observable bank and destination market traits.

Foreign banks improve general lending standards and access to finance (Giannetti and Ongena, 2012), enhance competition and lower the cost of financial intermediation (Claessens and van Horen, 2014a), thereby fostering real growth of local borrowers (Bruno and Hauswald, 2014). ${ }^{1}$ In the run up to the Great Financial crisis, foreign operations of banks grew signif-

\footnotetext{
We thank two anonymous referees and the editor for constructive and clear feedback. Comments by Claudia Buch, Lammertjan Dam, Galina Hale, Kaddee Russ, Christoph Schröder, and seminar participants at the Pacific Rim Meetings of the Western Economic Association, the International Banking workshop at Frankfurt School, the IMF/DNB conference on International Banking, and the European Economic Association meetings on an earlier version of this manuscript are highly appreciated. We are also grateful to Deutsche Bundesbank for providing access to data. The opinions expressed in this paper are those of the authors only. All remaining errors are our own.

* Corresponding author at: Halle Institute for Economic Research (IWH) and Otto-von-Guericke University, Kleine Märkerstraße 8, 06108 Halle (Saale), Germany.

E-mail addresses: r.j.galema@uu.nl (R. Galema), michael.koetter@iwh-halle.de (M. Koetter).

${ }^{1}$ Also note that financial services are a very important component of services trade. With $32 \%$ growth in 2007 it was the fastest growing segment of the services sector and it recovered fastest after the Great Financial Crisis. Global exports of services continued to increase by 5\% in 2014, compared with $0.5 \%$ for goods (WTO, 2009, 2011, 2015).
} 
icantly, with multinational banks from developed markets managing liquidity on a global scale (Cetorelli and Goldberg, 2012a). In the crisis' aftermath, cross-border lending collapsed (Giannetti and Laeven, 2012) and international banks retreated from numerous credit and funding markets. The withdrawal of funds from foreign activities was a function of how banks operated abroad: De Haas and van Horen (2013) show that "sudden stops" in cross-border lending were mitigated if foreign banks also operated foreign affiliates in host markets. In addition, the networks of multinational banks' foreign affiliates remained remarkably stable, whereas cross-border lending reduced significantly (Claessens and van Horen, 2015).

This paper combines detailed foreign activity data of German banks-the so-called External position of banks data (AUSTA "Auslandsstatus") ${ }^{2}$-with publicly available bank-level information in all major foreign credit markets to better understand the importance of host country banking sector efficiency. We use bank-level data between 2003 and 2012 to estimate the heterogeneous cost advantage of all German banks vis-à-vis 59 major foreign credit markets. This allows us to analyze the relative importance of cost advantage of banks in the home market versus cost advantage in potential host markets.

Our empirical work is inspired by the goods trade literature in which firm-level heterogeneity of productivity implies that some firms possess a variable cost advantage that compensates for the fixed costs of catering to foreign markets (see Helpman, 2006, for an overview). Exporting goods and services entails higher fixed cost compared to domestic activities and the operation of foreign affiliates is associated with even higher fixed set-up cost. Firm-level heterogeneity leads to a sorting of firms into foreign modes according to their productivity: The few largest, most productive firms pursue foreign direct investment in the form of affiliates, some sufficiently productive firms engage in international trade and export, whereas most firms operate only on domestic markets (Melitz, 2003; Bernard et al., 2003; Helpman et al., 2004). Most evidence focuses on manufacturing and goods trade, but Breinlich and Criscuolo (2011)'s findings suggest that firm-level productivity heterogeneity could also explain services trade.

A few theoretical multinational banking studies adapt these ideas, thereby complementing earlier approaches that hinge on the notion of portfolio theory and risk diversification to rationalize cross-border banking (Buch, 2000, 2003; Focarelli and Pozzolo, 2005). These novel theories explain cross-border banking activities with cross-country differences in banking technologies that generate bank-level heterogeneity in cost structures. De Blas and Russ (2013) embed banks with heterogeneous cost structures in a theoretical general equilibrium model. The low-cost leader bank can charge a markup and realize economic profits. If more efficient foreign banks offer cross-border lending, their model predicts a decline in loan rates and markups because consumers will demand credit from low-cost providers abroad. In contrast, the entry of foreign banks that are more efficient than domestic incumbents will not reduce loan rates, but increase markups and producer surplus accruing to owners of contesting banks from abroad. Niepmann (2015) provides a general equilibrium model in which perfectly competitive banks use a technology that is homogeneous within each country, but differs across countries. Paired with different exogenous factor endowments at home and abroad, the scope for cross-border banking activities in both loan and deposit markets arises. As a result, cross-border banking activities are driven by relative efficiency advantages of one banking system relative to another. Niepmann (2016) extends these results by allowing for within-country differences of bank efficiency. Heterogeneous production technologies together with differential factor endowments predict the observed modes of international banking: cross-border lending and funding or foreign direct investment. Banks are more likely to operate foreign affiliates if they incur less overhead costs relative to total assets, i.e. are more cost inefficient. This result is consistent with the Melitz-notion of sorting in the cross-section of banks in home markets.

We complement these important (primarily) theoretical contributions with empirical evidence based on micro-level data for both German home market banks and their potential foreign markets over the period 2003 until 2012. We estimate the marginal costs of banks for a sample of about 133,000 bank-year observations between 2003 and 2012. We combine the detailed information about the foreign lending of German banks reported in the AUSTA with publicly available Bankscope data. The AUSTA contains information about the international assets of German banks held via foreign branches and subsidiaries, year-by-year and country-by-country. The Bankscope data provides financial accounts for a large sample of the world's banks.

We predict the likelihood of home banks' foreign presence based on three cost measures. First, consistent with Melitztype arguments, higher Bank marginal cost of parent banks in Germany are expected to decrease the likelihood of foreign presence. Second, Marginal cost abroad, i.e. those of the average bank in host markets, are expected to increase the likelihood of foreign presence, because they increase the cost advantage of German banks compared to foreign incumbents. Third, inspired by De Blas and Russ (2013), the indicator of Cost leadership indicates whether German bank marginal costs are lower than marginal costs abroad, which is expected to make foreign presence more likely. Finally, country fixed effects, which should control for the unobserved heterogeneity that largely determines foreign market attractiveness, capture the fixed costs associated with the decision to set up a presence abroad.

This paper makes three contributions. First, we extend the empirical results from Niepmann $(2015,2016)$, because the panel structure of the AUSTA allows us to saturate specifications with a richer set of fixed effects to control for unobservables. In addition, we specify controls for previously omitted bank-level factors and other macro traits of foreign markets. Thereby, we can quantify the relative contribution of different types of cost advantage relative to competing bank-level and macroeconomic factors in explaining the extensive margin in international banking.

\footnotetext{
${ }^{2}$ Note that these data are used in a series of previous studies: Fiorentino et al. (2010) describe the AUSTA data in detail, which can be accessed via the Research Data Service Center of Deutsche Bundesbank. Examples of empirical applications are Buch et al. (2011, 2013, 2014), Frey and Kerl (2015), Kerl and Koch (2015), Galema et al. (2016).
} 
Second, we extend earlier studies on the international activities of banks using the AUSTA data that have mainly focused on home (cost) advantages. Based on descriptive evidence, Buch et al. (2011) show that only the largest, most productive banks engage in international affiliate lending. Buch et al. (2014) estimate the heterogeneous productivity distribution across German banks econometrically and relate it more directly to both the selection into different modes of crossborder banking (the extensive margin) as well as the volume of affiliate lending (the intensive margin).

Third, we utilize the cost distribution of banks in host markets using an approach based on individual bank data. Foreign market traits ${ }^{3}$ are well-documented determinants of foreign banking presence (e.g., Focarelli and Pozzolo, 2005; Claessens and van Horen, 2014a) as well as cross-border lending (e.g., Ongena et al., 2012; Giannetti and Ongena, 2012; Eichler et al., 2017), but most existing studies hardly ever employ cost estimates based on individual bank data, at home and abroad. ${ }^{4}$ Instead, they tend to resort to aggregate banking market statistics. An exception is Galema et al. (2016), who use the AUSTA data to assess the effect of interest rate differences on the amount of affiliate lending and parent funding of German banks. We complement their analysis in three major respects. First, we explain the location choice of foreign affiliates whereas they investigate only the intensive margin. Second, they disregard observable risk traits of German banks, which we use to assess the relative explanatory power of cost advantage. Third, they analyze a pre-crisis sample of German banks, whereas we exploit AUSTA data between 2003 and 2012.

Like Breinlich and Criscuolo (2011) and Buch et al. (2011), our results reflect evidence on goods trade firms: A decrease in banks marginal costs is associated with a higher likelihood of conducting foreign affiliate lending. In our preferred specification that includes bank and macro controls and time and banking group fixed effects, a one percentage point increase in bank marginal costs is associated with a decline in the probability to operate foreign affiliates of about 4.6 percentage points. Whereas the average marginal costs of banks abroad have no significant effect, an indicator variable that gauges if a German bank marginal costs are lower than average marginal costs abroad is significantly positive. We reject a model without cost advantage variables, but especially bank-specific covariates that gauge size and risk explain a large part of the variation in foreign affiliate activity. Cost advantage does play a role, but it fails to explain as much of the observed variation as in international trade of manufacturing goods and services. Instead, risk and return considerations take center stage in explaining activities in the international financial industry.

The remainder of this paper is organized as follows. In Section 2, we present the data and the empirical specifications to estimate foreign presence. We discuss our main results in Section 3 and present additional findings and robustness checks in Section 4. We conclude in Section 5.

\section{Method and data}

\subsection{Regression model}

We estimate the probability of foreign presence as a function of the two different types of cost advantage. We first define an indicator variable $T_{i j t}$ equal to one when bank $i$ lends through an affiliate in country $j$ at time $t$ and zero otherwise. In each year, each bank could be present in each one of the countries that are in the data set in that year. So for a typical bank in a typicalyear, $T_{i j t}$ equals one for the countries where it is lending through affiliates, and zero for all other countries the bank could have been lending through affiliates. Let $\rho_{i j t}$ be the probability that bank $i$ lends through an affiliate in country $j$ at time $t$.

$$
\begin{aligned}
\rho_{i j t}= & \operatorname{Pr}\left(T_{i j t}=1 \mid \text { observed variables }\right) \\
= & \operatorname{Pr}\left(\gamma_{0}+\gamma_{1} c_{i t}+\gamma_{2} c_{j t}+\gamma_{3} I\left(c_{i t}<c_{j t}\right)\right. \\
& \left.+\gamma_{4} \text { Macro controls } \text { Macr }_{j t}+\gamma_{5} \text { Parent controls }{ }_{i t}+\delta_{j}+\delta_{t}\right) .
\end{aligned}
$$

To determine the baseline specification, we use a range of alternative estimators to obtain the parameters of Eq. (1): OLS, probit, logit and a complementary log-log (cloglog) model. We also estimate a linear probability model (OLS) because the specification of fixed effects in Eq. (1) could result in an incidental parameter problem. Our preferred model is a (cloglog) model because of the few cases of foreign affiliate lending in the sample. ${ }^{5}$ All covariates are lagged by one year to avoid simultaneity by construction. Because this does not solve the issue of possible reverse causality, our estimates should be interpreted as correlations. We cluster standard errors at the country level throughout and specify country and year fixed effects, respectively.

We distinguish the marginal costs of each parent bank in Germany, Bank marginal costs $\left(c_{i t}\right)$, and the marginal costs in foreign host countries, Marginal costs abroad $\left(c_{j t}\right)$. They equal the total derivative of an estimated stochastic cost frontier in the vein of Berger and Humphrey (1997), Delis (2012), or Koetter et al. (2012). ${ }^{6}$ The former gauges the cost advantage

\footnotetext{
${ }^{3}$ Foreign market traits include distance, average bank efficiency, institutional quality, central bank independence, and others.

4 Consider for instance, Buch et al. (2013), Frey and Kerl (2015), and Kerl and Koch (2015), who investigate the effects of international ties of German banks for domestic competition, internal capital markets, and policy transmission, but do not explicitly consider individual bank data to construct cost estimates for banks in foreign banking markets.

5 We thank one referee for suggesting the complementary log-log model.

${ }^{6}$ Note that we exclude foreign subsidiaries of German banks in countries $j$. Appendix A provides a more detailed description. We also derive marginal costs from cost functions estimated for each pair of countries $j$ and Germany to allow for heterogeneous intermediation technologies. Results are available upon request.
} 
of banks in the German home market. Thereby it directly reflects the firm-specific heterogeneity of cost advantage known from trade theories inspired by Melitz (2003) that should lead to a sorting of German banks into increasingly complex foreign entry modes. $c_{j t}$ captures potential cost advantage of German banks in foreign markets. This variable allows us to test whether-everything else equal-a higher average efficiency of host country banks has an effect on the average probability that German banks have an affiliate there.

De Blas and Russ (2013) show that the choice to enter foreign banking markets with affiliates instead of cross-border lending depends on whether the contesting banks can undercut the marginal cost of incumbent banks to realize monopolistic rents. Inspired by this result, we also specify a dummy variable: Cost leadership. It is equal to one if $I\left(c_{i t}<c_{j t}\right)$, i.e. when the parent bank's marginal cost is lower than the marginal cost of the mean bank in country $j$.

\subsection{Measurement and data}

Sampling and sources. Our main data are bank-level variables that result from the combination of foreign affiliate lending reported to the AUSTA database-accessible via the Research Data and Service Center of Deutsche Bundesbank-with financial accounts data of parent banks obtained from Bankscope. In both samples, the universe of financial institutions comprises all universal banks from the three banking sectors, sometimes also referred to as the "three pillars", in Germany: commercial, savings, and cooperative banks (Deutsche Bundesbank, 2013). ${ }^{8}$ Banks from these three sectors must not merge across pillars and have different ownership structures, but are all free to bank across national borders. Within each sector, a two-tier structure exists. Large, (inter)nationally active commercials, Landesbanken and central cooperatives act as clearing houses and capital market gateways for their smaller local counterparts. Regional savings and cooperative banks, in turn, operate on de jure and de facto regionally delineated markets (German Council of Economic Experts, 2013). However, they can and do follow their regional corporate customers abroad (see for example Maß, 2007). These data are then combined with macro data from various sources described below. A description of the matching process can be found in Appendix B and variable definitions are provided in Appendix Table B.1.

Foreign presence. The dependent variable in Eq. (1), $T_{i j t}$, equals one for positive stocks of the variable Loans and advances reported by German banks' branches and subsidiaries, affiliates for short, to the AUSTA. The data covers the period 20032012 and consists of end-of-year amounts of loans and advances by affiliates to foreign enterprises, households, and general government of each bank in each host markets $j$ in Euros. ${ }^{9}$ Table 1 provides descriptive statistics for this sample.

Panel A shows that most of the 54 banks with affiliates are commercial banks. Panel B shows that they also operate most affiliates: up to 240 in 2003. Commercial banks are also most dynamic in terms of number of entries and exits over the sample period..$^{10}$ Still, compared to the number of foreign affiliates, entries and exits are overall fairly modest, which is consistent with the reported overall stability of foreign affiliate networks in comparison to fairly footloose cross-border lending after the financial turmoil (see Claessens and van Horen, 2015). The number of affiliates was high up and until the Great Financial crisis. After 2008, the number of German affiliates of commercials declined drastically, which is consistent with the fall in foreign presence of banks from OECD countries associated with the crisis (Claessens and van Horen, 2015). The number of affiliates of cooperatives remained fairly stable over the entire sample period. What is remarkable though is the decline of foreign affiliates in the savings bank sector from 71 in 2009 to 49 in 2012. This contraction can partly be attributed to the requirement of the European Commission (2012) to close foreign branches of central savings banks that received state aid.

The consideration of subsidiaries and branches in the AUSTA data reveals potentially important complementarities with publicly available data compiled by Claessens and van Horen (2014a,b) that are confined to foreign subsidiaries. Banks with affiliates from the savings and cooperative banking sector are mostly, but not exclusively, the large head institutions. Across all sectors, the average international bank operates affiliates in about 23 countries (see Panel A). Fig. 1 visualizes the average number of German banks with affiliates in global markets for the 2003-2012 estimation sample. German bank presence is concentrated in the developed world.

Cost leadership variables. We measure the different types of cost advantage by estimating bank-specific marginal costs of both German parent and foreign market incumbents from a world cost function using stochastic frontier analysis. We use Bankscope data from unconsolidated financial statements in all available countries. We select all universal banks between 2003 and 2012 that are classified as commercial, savings, or cooperative banks (Deutsche Bundesbank, 2013). We drop entries with missing or negative data for the three factors prices, three outputs, costs, equity, total assets, and risk controls and deflate all monetary volumes to 2005 prices using country-specific consumer price indexes. Factor prices are winsorized

\footnotetext{
${ }^{7}$ Stricter thresholds used in previous versions of this paper, such as the 5th percentile of the marginal cost distribution, yielded qualitatively very similar results and are available upon request.

${ }^{8}$ Ideally, we would also control for the possibility that foreign banks can enter the German market reciprocally, i.e. the existence of intra-industry trade which is also central in gravity-models of trade and banking, see von Peter (2017). According to Deutsche Bundesbank (2016), 106 branches of foreign banks operated in Germany as of February 2016. Their aggregate balance sheet size of 311.8 billion Euros represents a market share of $3.9 \%$ compared to the aggregate balance sheet of 7955.7 Billion Euros. As such, this banking group is probably not of central importance to our results on cost advantage. We have to exclude these banks from our analysis because most foreign branches do not report financial accounts that are necessary to estimate marginal costs.

${ }^{9}$ We use field 123 in column 01 of form R11 and subtract interbank loans reported in fields 103 and 104 in column 01, see the reporting form here.

${ }^{10}$ Note that entry and exit is not defined as physical entry and exit, which we unfortunately do not observe directly. Instead, Entry in year $t$ indicates the number of affiliates that entered the AUSTA reporting between year $t$ and year $t+1$. Likewise, exit indicates the number of affiliates that no longer report between year $t$ and year $t+1$ in the AUSTA. An obvious caveat is thus reporting bias.
} 
Table 1

Summary statistics for foreign affiliates.

\begin{tabular}{|c|c|c|c|c|c|c|c|c|c|c|c|c|}
\hline Variable & Group & 2003 & 2004 & 2005 & 2006 & 2007 & 2008 & 2009 & 2010 & 2011 & 2012 & All \\
\hline \multicolumn{13}{|l|}{ Panel A: Banks and countries } \\
\hline \multirow[t]{4}{*}{ Number of banks } & Commercials & 61 & 67 & 74 & 78 & 75 & 73 & 71 & 71 & 71 & 73 & 111 \\
\hline & Savings & 380 & 415 & 414 & 417 & 418 & 411 & 411 & 411 & 406 & 405 & 468 \\
\hline & Cooperatives & 488 & 553 & 548 & 577 & 887 & 888 & 876 & 894 & 888 & 871 & 1023 \\
\hline & All & 929 & 1035 & 1036 & 1072 & 1380 & 1372 & 1358 & 1376 & 1365 & 1349 & 1600 \\
\hline \multirow[t]{4}{*}{ Number of banks abroad } & Commercials & 18 & 13 & 18 & 19 & 18 & 16 & 20 & 18 & 18 & 19 & 33 \\
\hline & Savings & 7 & 9 & 10 & 10 & 10 & 10 & 10 & 10 & 10 & 9 & 13 \\
\hline & Cooperatives & 4 & 5 & 5 & 7 & 7 & 7 & 7 & 5 & 5 & 6 & 9 \\
\hline & All & 29 & 27 & 33 & 36 & 35 & 33 & 37 & 33 & 33 & 34 & 54 \\
\hline \multirow[t]{4}{*}{ Number of countries with affiliate } & Commercials & 49 & 49 & 48 & 50 & 46 & 48 & 49 & 52 & 54 & 54 & 59 \\
\hline & Savings & 26 & 41 & 44 & 47 & 45 & 49 & 48 & 52 & 51 & 49 & 58 \\
\hline & Cooperatives & 33 & 33 & 29 & 34 & 36 & 39 & 41 & 43 & 44 & 42 & 52 \\
\hline & All & 49 & 49 & 48 & 50 & 46 & 49 & 50 & 54 & 55 & 55 & 59 \\
\hline \multirow{4}{*}{$\begin{array}{l}\text { Average number of countries with } \\
\text { affiliate }\end{array}$} & Commercials & 32.71 & 39.40 & 21.58 & 22.36 & 21.13 & 23.31 & 21.50 & 24.09 & 23.25 & 23.83 & 23.95 \\
\hline & Savings & 18.00 & 29.50 & 21.00 & 22.00 & 25.00 & 28.60 & 28.29 & 31.50 & 30.57 & 25.60 & 27.36 \\
\hline & Cooperatives & 17.00 & 14.00 & 12.67 & 9.50 & 12.67 & 12.50 & 14.00 & 18.67 & 22.50 & 14.67 & 14.23 \\
\hline & All & 28.10 & 29.80 & 19.94 & 19.95 & 20.87 & 22.55 & 22.64 & 25.50 & 25.62 & 22.90 & 23.19 \\
\hline \multicolumn{13}{|l|}{ Panel B: Number of foreign affiliates } \\
\hline \multirow[t]{3}{*}{ Affiliates commercials } & Number & 240 & 226 & 219 & 210 & 184 & 183 & 165 & 179 & 168 & 166 & 1940 \\
\hline & Entry & 15 & 16 & 20 & 6 & 16 & 15 & 28 & 4 & 8 & & 128 \\
\hline & Exit & 29 & 23 & 29 & 32 & 17 & 33 & 14 & 15 & 10 & & 202 \\
\hline \multirow{3}{*}{ Affiliates savings } & Number & 67 & 72 & 69 & 66 & 66 & 73 & 71 & 58 & 53 & 49 & 644 \\
\hline & Entry & 11 & 4 & 4 & 3 & 11 & 4 & 2 & 1 & 0 & & 40 \\
\hline & Exit & 6 & 7 & 7 & 3 & 4 & 6 & 15 & 6 & 4 & & 58 \\
\hline \multirow[t]{3}{*}{ Affiliates cooperatives } & Number & 19 & 15 & 16 & 17 & 16 & 17 & 17 & 15 & 15 & 15 & 162 \\
\hline & Entry & 0 & 1 & 2 & 0 & 1 & 0 & 0 & 0 & 2 & & 6 \\
\hline & Exit & 4 & 0 & 1 & 1 & 0 & 0 & 2 & 0 & 2 & & 10 \\
\hline
\end{tabular}

Notes: This table reports summary statistics for each year and for all years 2003-2012 in the final column All. Panel A reports the unique Number of banks that are in the regression sample. Of these banks it reports the unique Number of banks abroad. The Number of countries with affiliate is the number of unique countries that have at least one affiliate. The Average number of countries with affiliate is the mean number of countries within a group (commercials, savings, cooperatives, and all) where banks operate affiliates. Panel B reports the sum total of affiliates abroad per banking pillar and year. The Number indicates the total sum of number of foreign affiliates of German banks. Entry in year $t$ indicates the number of affiliates that physically entered between year $t$ and year $t+1$. Likewise, exit indicates the number of affiliates that exited between year $t$ and year $t+1$. The final column All indicates the total sum of the number of foreign affiliates and the sum of physical entry and exit over the sample.

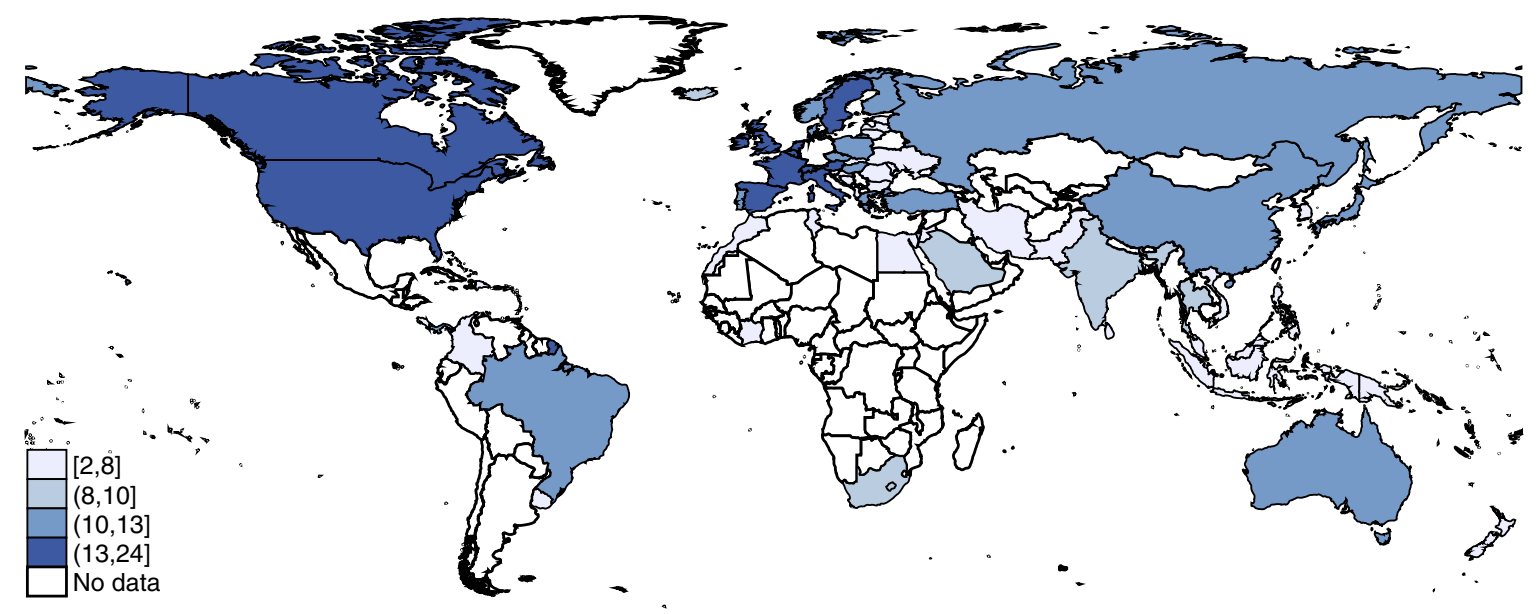

Fig. 1. Average number of German banks present abroad per country.

at the $1 \%$ level to control for outliers. After this culling, we estimate marginal costs for a sample of banks in 103 countries with 133,204 bank-year observations in total. Appendix A provides details on the cost estimation and Appendix Table A.1 shows descriptive statistics. 
Parent controls. Risk-return considerations are likely to be important drivers of internationalization decisions in banking. Therefore, we first include return on equity (roe), which equals pre-impairment operating profit divided by equity. Second, we gauge insolvency risk by the z-score (zs) (Laeven and Levine, 2009). It equals the sum of return on assets (RoA) and the capital ratio (Equity/total assets, TA) divided by the standard deviation of return on assets over the sample period. Z-scores reflect the number of standard deviations that a bank's RoA must fall below its expected value before equity is depleted. Lower z-scores therefore indicate riskier banks. Third, we specify credit risk (cs) as measured by loan impairment charges over gross loans. Finally, we follow Aviat and Coeurdacier (2007) and specify a quintile indicator (sq) based on the distribution of total assets at home in each year to measure bank size. ${ }^{11}$

Macro controls. Parent banks usually have the possibility to refinance through internal capital markets (Cetorelli and Goldberg, 2012a,b). Therefore, we include average loan rates in host markets, $r_{j t}^{*}$, which are defined as foreign bank revenues divided by total assets. In addition to cost differences, Focarelli and Pozzolo (2005) highlight that potential profits are presumably the most important reason to set up foreign affiliates in banking. Therefore, we test if the foreign net interest margin $n_{j t}$ co-determines foreign presence. It equals the difference between interest rate revenue relative to gross loans and interest expenses relative to customer deposits in each country $j$ in year $t$. Note that we measure both variables using Bankscope data. Consistent with the cost advantage proxies, we then take the average across all banks in each country-year.

The results from Niepmann $(2015,2016)$ show that relative factor endowments and the productivity of capital matter for foreign bank lending. The capital stock $\left(k_{j t}\right)$ and marginal productivity of capital $\left(m p k_{j t}\right)$ in foreign countries control for the potential size of the foreign lending market. We calculate these following Caselli and Feyrer (2007) and using data from the Penn World Tables (PWT 9.0, Feenstra et al., 2015).

In line with the foreign liability-asset gap in Niepmann (2015), we specify the Foreign funding share $\left(\alpha_{j t}\right)$. It is the ratio of local currency liabilities on local residents relative to local currency claims on local residents. These data are from the Bank for International Settlement's consolidated banking statistics, Tables B.2A:L and A:M. The variable measures the extent to which foreign lending is financed by local deposits. A cost advantage could arise because parent banks have better access to global wholesale funding markets or because parent banks "export" their financial know-how to foreign markets. In the former case, the foreign funding share would reduce the probability of foreign presence, but increase it in the latter case.

Claessens and van Horen (2014b) show that location choices also depend on the competition from other foreign banks that are active in host markets. The expected fraction of host country lending the bank could capture is measured by the percentage of foreign banks that are active in the foreign country $\left(\beta_{j t}\right)$. We use the bank ownership database of Claessens and van Horen (2015) to calculate this variable. A higher fraction of foreign banks should reduce the probability of foreign presence.

\section{Main results}

\subsection{Summary statistics cost advantage}

Table 2 summarizes the main test variables to gauge cost advantage by banking group: Bank marginal costs at home, Marginal costs abroad and the Cost leadership dummy. ${ }^{12}$ The descriptives are shown at the bank-country-year level (ijt) for banks without affiliate activity in the upper panel (Non-affiliate) and with foreign affiliate activity in the middle panel (Affiliate). Three main features are noteworthy.

First, foreign lending through affiliates is rare. Only 5473 out of 621,746 ijt-observations indicate that at least one of the 54 parent banks in Table 1 was active in at least one of the 59 countries with an affiliate in a given year, resembling an unconditional probability of $0.9 \%$. The sparseness of the event is in line with earlier studies accounting for different modes of international banking, such as Buch et al. $(2011,2014)$. This pattern underscores that an analysis of cross-border (affiliate) lending volumes without accounting for the non-random self-selection of banks into maintaining foreign affiliate networks is problematic. Internationalization patterns differ widely across banking sectors, whereas the unconditional probability for a commercial bank to lend via affiliates is around $10 \%$, it is virtually zero for the numerous, but smallest cooperative banks.

Second, the comparison of parent Bank marginal costs in the final columns "All" shows that these are not very different for banks with and without foreign affiliate activities. But it is important to distinguish between different banking groups. Commercial banks with affiliates abroad exhibit significantly lower marginal cost compared to peers at home without foreign affiliates (3.9\% versus $5.1 \%$ ). This difference is comparable for cooperative banks (2.9\% versus $4.3 \%$ ), but not for savings banks ( $4.5 \%$ versus $4.3 \%)$. Therefore, these data indicate that cost leadership in the home market alone is insufficient to explain which banks operate foreign affiliates. Therefore, we compare and quantify below, which other bank- or market-specific factors are relevant.

Third, the summary statistics across all banking groups indicate that Marginal costs abroad tend to be higher in markets without foreign affiliate activity. Put differently, the unconditional probability to observe affiliate lending is larger in foreign markets where the average incumbent is more cost-efficient. For the full sample of non-affiliate active observations, the Marginal costs abroad is $4.5 \%$ and compares to $4.1 \%$ in the sample of affiliate-active observations. German parent banks are overall

\footnotetext{
11 Appendix Table C.3 shows robustness checks with four alternative size proxies.

12 Appendix Table C.1 provides summary statistics on the control variables.
} 
Table 2

Summary statistics ijt-dimension according to presence abroad.

\begin{tabular}{|c|c|c|c|c|c|c|c|c|c|c|c|c|}
\hline & \multicolumn{3}{|c|}{ Commercials } & \multicolumn{3}{|c|}{ Savings } & \multicolumn{3}{|c|}{ Cooperatives } & \multicolumn{3}{|c|}{ All } \\
\hline & Mean & $S D$ & $N$ & Mean & $S D$ & $N$ & Mean & $S D$ & $N$ & Mean & $S D$ & $N$ \\
\hline \multicolumn{13}{|l|}{ Non-affiliate } \\
\hline Bank marginal costs $\left(c_{i t}\right)$ & 0.051 & 0.068 & 32,781 & 0.043 & 0.010 & 204,687 & 0.043 & 0.011 & 378,805 & 0.043 & 0.019 & 616,273 \\
\hline Marginal costs abroad $\left(c_{j t}\right)$ & 0.045 & 0.033 & 32,781 & 0.045 & 0.032 & 204,687 & 0.045 & 0.031 & 378,805 & 0.045 & 0.032 & 616,273 \\
\hline Cost leadership $\left(I\left(c_{i t}<c_{j t}\right)\right)$ & 0.466 & 0.499 & 32,781 & 0.437 & 0.496 & 204,687 & 0.453 & 0.498 & 378,805 & 0.448 & 0.497 & 616,273 \\
\hline \multicolumn{13}{|l|}{ Affiliate } \\
\hline Bank marginal costs $\left(c_{i t}\right)$ & 0.039 & 0.016 & 3274 & 0.045 & 0.023 & 1706 & 0.029 & 0.010 & 493 & 0.040 & 0.019 & 5473 \\
\hline Marginal costs abroad $\left(c_{j t}\right)$ & 0.040 & 0.029 & 3274 & 0.041 & 0.029 & 1706 & 0.042 & 0.030 & 493 & 0.041 & 0.029 & 5473 \\
\hline Cost leadership $\left(I\left(c_{i t}<c_{j t}\right)\right)$ & 0.454 & 0.498 & 3274 & 0.409 & 0.492 & 1706 & 0.682 & 0.466 & 493 & 0.460 & 0.498 & 5473 \\
\hline \multicolumn{13}{|l|}{ All } \\
\hline Bank marginal costs $\left(c_{i t}\right)$ & 0.050 & 0.065 & 36,055 & 0.043 & 0.010 & 206,393 & 0.043 & 0.011 & 379,298 & 0.043 & 0.019 & 621,746 \\
\hline Marginal costs abroad $\left(c_{j t}\right)$ & 0.045 & 0.032 & 36,055 & 0.045 & 0.032 & 206,393 & 0.045 & 0.031 & 379,298 & 0.045 & 0.032 & 621,746 \\
\hline Cost leadership $\left(I\left(c_{i t}<c_{j t}\right)\right)$ & 0.465 & 0.499 & 36,055 & 0.437 & 0.496 & 206,393 & 0.453 & 0.498 & 379,298 & 0.448 & 0.497 & 621,746 \\
\hline
\end{tabular}

Notes: This table reports summary statistics on the main test variables: estimated marginal costs and the cost leadership indicator per banking group. Each group includes the large and central as well as the regional banks. SD indicates standard deviation, $N$ indicates the number of observations. All marginal costs follow from the sum of the derivatives of the cost function w.r.t to outputs $y_{1}, y_{2}$, and $y_{3}$. We take the average of the distribution of costs in each host country $i$ at time $t$ or in Germany at time $t$.

in around $45 \%$ of all cases the cost leader relative to incumbent banks in foreign markets. But they are hardly more often cost leaders in non-affiliate active markets compared to affiliate active ones (44.8\% versus $46.0 \%)$.

To assess the overall impact of cost advantage at home and abroad in comparison with other bank- and country-specific traits on foreign affiliate activity, we turn next to the regression approach reflected by Eq. (1).

\subsection{Foreign affiliates: cost advantage or other factors?}

Table 3 presents the marginal effect estimates of Eq. (1) using the complimentary log-log model. Standard errors are clustered at the country level. We prefer this estimator to mitigate the zero-inflation bias in discrete regression settings (see King and Zeng, 2001; Baetschmann and Winkelmann, 2013; or Winkelmann and Staub, 2013). ${ }^{13}$ To assess the relative importance of cost leadership in explaining foreign presence, we specify in Table 3 different (combinations of) fixed effects, bank-, and country-specific control variables. We include year fixed effects in all specifications.

Column (1) shows the results from a parsimonious specification that includes only Bank marginal costs, Marginal costs abroad, and the Cost leadership indicator. The effect of Bank marginal costs is significantly negative and thus in line with theory and previous evidence. German parent banks with less efficient cost structures, as reflected by their marginal cost estimate, are less likely to operate affiliates in foreign markets and presumably sort themselves either into domestic operations only or conduct cross-border lending. Marginal costs abroad is also significantly negative, albeit with a a substantially smaller marginal effect. This result is counterintuitive at first sight because it implies that German banks are less likely to enter markets where they would be able to undercut incumbent banks, as predicted by De Blas and Russ (2013). But those effects might be partially gauged by the Cost leadership variable, which is not statistically significant. An explanation for the significantly negative effect of Marginal costs abroad relates to a volume argument. Conditional on being able to compete, German banks are attracted to more competitive banking markets, where costs are lower, but markets are also larger. This explanation is consistent with the international trade theory by Melitz and Ottaviano (2008), where competitive firms are attracted to competitive markets as long as they are still able to realize positive margins.

The explanatory power of this sparse specification is, however, very small. Therefore, we specify banking group dummies in column (2) to address the substantial heterogeneity across banking sectors shown in Table $2 .{ }^{14}$ These fixed effects increase the pseudo R-squared by about 20 percentage points and leave the sign and significance of the three empirical measures to gauge cost advantage unchanged. The magnitude of cost advantage in the German home market is only a third of the effect in column (1) though. This result corroborates the importance of accounting for unobservables and potentially other factors omitted thus far.

In column (3) we add control variables to gauge competing drivers of bank-level cost advantage heterogeneity as well as the risk and return characteristics that were found to be significant in studies taking a portfolio perspective (e.g. Buch, 2000, 2003; Focarelli and Pozzolo, 2005). As a result, pseudo R-square increases by another 20 percentage points. The estimated cost advantage effects remain qualitatively stable, but they become smaller in magnitude. The estimated marginal effects

\footnotetext{
13 Table C.2 in the appendix shows, however, that the results presented below are qualitatively very similar across alternative estimators. Estimation results of Eq. (1) are reported there as marginal effects and pertain to a sparsely specified model with macro controls and fixed effects for years, countries, and banking groups, but no further bank controls. Log-likelihood tests for the nested three non-linear models, in fact, reject significant differences across models.

14 We generate one group indicator for large banks from all three sectors, i.e. large commercial banks, Landesbanken, and central cooperative banks and three groups of regional banks per sector.
} 
Table 3

Cost leadership and the probability of foreign affiliate activity: Main estimates.

\begin{tabular}{|c|c|c|c|c|c|c|c|c|}
\hline & $(1)$ & $(2)$ & $(3)$ & $(4)$ & $(5)$ & $(6)$ & $(7)$ & $(8)$ \\
\hline Bank marginal costs $\left(c_{i t}\right)$ & $\begin{array}{l}-0.3251^{* * *} \\
{[0.022]}\end{array}$ & $\begin{array}{l}-0.1180^{* * *} \\
{[0.013]}\end{array}$ & $\begin{array}{l}-0.0796^{* * *} \\
{[0.012]}\end{array}$ & $\begin{array}{l}-0.0692^{* * *} \\
{[0.013]}\end{array}$ & $\begin{array}{l}-0.0458^{* * *} \\
{[0.011]}\end{array}$ & & $\begin{array}{l}-0.0558^{* * *} \\
{[0.010]}\end{array}$ & $\begin{array}{l}-0.0881^{* * *} \\
{[0.010]}\end{array}$ \\
\hline Marginal costs abroad $\left(c_{j t}\right)$ & $\begin{array}{l}-0.0472^{* *} \\
{[0.019]}\end{array}$ & $\begin{array}{l}-0.0312^{* *} \\
{[0.014]}\end{array}$ & $\begin{array}{l}-0.0271^{* *} \\
{[0.013]}\end{array}$ & $\begin{array}{l}-0.0259^{*} \\
{[0.014]}\end{array}$ & $\begin{array}{l}-0.0108 \\
{[0.007]}\end{array}$ & & $\begin{array}{l}-0.0107^{*} \\
{[0.006]}\end{array}$ & $\begin{array}{l}-0.0134^{*} \\
{[0.008]}\end{array}$ \\
\hline Cost leadership $\left(I\left(c_{i t}<c_{j t}\right)\right)$ & $\begin{array}{l}0.0009 \\
{[0.001]}\end{array}$ & $\begin{array}{l}-0.0006 \\
{[0.001]}\end{array}$ & $\begin{array}{l}-0.0009 \\
{[0.001]}\end{array}$ & $\begin{array}{l}-0.0002 \\
{[0.001]}\end{array}$ & $\begin{array}{l}0.0016^{* * *} \\
{[0.001]}\end{array}$ & & $\begin{array}{l}0.0010^{*} \\
{[0.001]}\end{array}$ & $\begin{array}{l}0.0020^{* * * *} \\
{[0.001]}\end{array}$ \\
\hline Return on equity (roe) & & & $\begin{array}{l}-0.0001^{* * *} \\
{[0.000]}\end{array}$ & $\begin{array}{l}-0.0001^{* * *} \\
{[0.000]}\end{array}$ & $\begin{array}{l}-0.0001^{\text {*** }} \\
{[0.000]}\end{array}$ & $\begin{array}{l}-0.0002^{* * *} \\
{[0.000]}\end{array}$ & $\begin{array}{l}-0.0001^{* * *} \\
{[0.000]}\end{array}$ & \\
\hline Z-score $(z s)$ & & & $\begin{array}{l}-0.0005^{* * *} \\
{[0.000]}\end{array}$ & $\begin{array}{l}-0.0005^{* * *} \\
{[0.000]}\end{array}$ & $\begin{array}{l}-0.0005^{\text {*** }} \\
{[0.000]}\end{array}$ & $\begin{array}{l}-0.0005^{* * *} \\
{[0.000]}\end{array}$ & $\begin{array}{l}-0.0005^{* * *} \\
{[0.000]}\end{array}$ & \\
\hline Credit risk $(\mathrm{cr})$ & & & $\begin{array}{l}-0.0003^{* * *} \\
{[0.000]}\end{array}$ & $\begin{array}{l}-0.0003^{* * *} \\
{[0.000]}\end{array}$ & $\begin{array}{l}-0.0003^{* * *} \\
{[0.000]}\end{array}$ & $\begin{array}{l}-0.0004^{* * *} \\
{[0.000]}\end{array}$ & $\begin{array}{l}-0.0003^{* * *} \\
{[0.000]}\end{array}$ & \\
\hline Size quintile $(s q)$ & & & $\begin{array}{l}0.0242^{* * *} \\
{[0.002]}\end{array}$ & $\begin{array}{l}0.0249^{* * *} \\
{[0.002]}\end{array}$ & $\begin{array}{l}0.0244^{* * *} \\
{[0.002]}\end{array}$ & $\begin{array}{l}0.0247^{* * *} \\
{[0.002]}\end{array}$ & $\begin{array}{l}0.0235^{* * *} \\
{[0.002]}\end{array}$ & \\
\hline Price of capital abroad $\left(r_{j t}^{*}\right)$ & & & & $\begin{array}{l}-0.0274^{* *} \\
{[0.012]}\end{array}$ & $\begin{array}{l}0.0011 \\
{[0.005]}\end{array}$ & $\begin{array}{l}-0.0006 \\
{[0.003]}\end{array}$ & & $\begin{array}{l}0.0015 \\
{[0.005]}\end{array}$ \\
\hline Net interest margin abroad $\left(n_{j t}\right)$ & & & & $\begin{array}{l}0.0320^{* * *} \\
{[0.010]}\end{array}$ & $\begin{array}{l}-0.0028 \\
{[0.005]}\end{array}$ & $\begin{array}{l}-0.0033 \\
{[0.004]}\end{array}$ & & $\begin{array}{l}-0.0026 \\
{[0.005]}\end{array}$ \\
\hline Capital stock $\left(K_{j t}\right)$ & & & & $\begin{array}{l}0.0001^{* * *} \\
{[0.000]}\end{array}$ & $\begin{array}{l}-0.0003^{* *} \\
{[0.000]}\end{array}$ & $\begin{array}{l}-0.0003^{* * *} \\
{[0.000]}\end{array}$ & & $\begin{array}{l}-0.0003^{* *} \\
{[0.000]}\end{array}$ \\
\hline Marginal product of capital $\left(M P K_{j t}\right)$ & & & & $\begin{array}{l}-0.0194^{* * *} \\
{[0.007]}\end{array}$ & $\begin{array}{l}0.0082 \\
{[0.006]}\end{array}$ & $\begin{array}{l}0.0086 \\
{[0.007]}\end{array}$ & & $\begin{array}{l}0.0085 \\
{[0.007]}\end{array}$ \\
\hline Foreign funding share $\left(\alpha_{j t}\right)$ & & & & $\begin{array}{l}-0.0004 \\
{[0.002]}\end{array}$ & $\begin{array}{l}0.0000 \\
{[0.000]}\end{array}$ & $\begin{array}{l}0.0000 \\
{[0.000]}\end{array}$ & & $\begin{array}{l}-0.0000 \\
{[0.000]}\end{array}$ \\
\hline Openness foreign market $\left(\beta_{j t}\right)$ & & & & $\begin{array}{l}-0.0033 \\
{[0.002]}\end{array}$ & $\begin{array}{l}-0.0011 \\
{[0.003]}\end{array}$ & $\begin{array}{l}-0.0003 \\
{[0.003]}\end{array}$ & & $\begin{array}{l}-0.0018 \\
{[0.003]}\end{array}$ \\
\hline Observations & 744,386 & 744,386 & 744,386 & 621,746 & 621,746 & 621,746 & 744,386 & 621,746 \\
\hline Observations non-zero & 6142 & 6142 & 6142 & 5473 & 5473 & 5473 & 6142 & 5473 \\
\hline Number of banks & 1600 & 1600 & 1600 & 1600 & 1600 & 1600 & 1600 & 1600 \\
\hline Number of countries & 75 & 75 & 75 & 59 & 59 & 59 & 75 & 59 \\
\hline Country FE & no & no & no & no & yes & yes & yes & yes \\
\hline Banking group FE & no & yes & yes & yes & yes & yes & yes & yes \\
\hline Pseudo R-squared & 0.016 & 0.222 & 0.431 & 0.437 & 0.458 & 0.456 & 0.461 & 0.250 \\
\hline AIC & 70,027 & 55,397 & 40,534 & 35,335 & 34,026 & 34,172 & 38,425 & 47,095 \\
\hline LR $\chi^{2}$ & 31611.9670 & 16978.4730 & $\begin{array}{c}- \\
2106.7010\end{array}$ & $\begin{array}{c}- \\
1306.9921\end{array}$ & um & 152.5596 & $\mathrm{um}$ & 13077.7800 \\
\hline LR p-value & 0.0000 & 0.0000 & 1.0000 & 1.0000 & um & 0.0000 & um & 0.0000 \\
\hline
\end{tabular}

Notes: This table reports the marginal effects of estimating the cloglog model in Eq. (1) for the years 2003-2012. The dependent variable is an indicator equal to one if bank $i$ lends to country $j$ through an affiliate at time $t$. All explanatory variables are lagged by one period. All estimations include year fixed effects. AIC indicates the Akaike information criterion. We perform likelihood ratio (LR) tests in which Column (7) is the unrestricted model (um) for model (1), (2) and (3) and column (5) is the unrestricted model ( $\mathrm{um}$ ) for model (4), (6) and (8). Standard errors are clustered at the country level and are reported in brackets. ${ }^{* * *} \mathrm{p}<.01,{ }^{* *} \mathrm{p}<.05,{ }^{*} \mathrm{p}<0.1$.

of bank-specific covariates suggest that less profitable, less stable, and larger banks are more likely to operate foreign affiliates, which does not bode well considering affiliates' importance in propagating shocks (Cetorelli and Goldberg, 2012a; Kick et al., 2016).

So far we have neglected the important insights from theoretical work by De Blas and Russ (2013) and Niepmann (2015, 2016) that both competitive conditions in potential host markets as well as heterogeneous factor endowments across countries are crucial determinants of cross-border banking activities in general, and the entry choice of bank affiliates in particular. Therefore, we add country controls in columns (4) and country fixed effects in column (5), which also capture the fixed costs of setting up a presence abroad. Adding country controls reduces the sample size to 621,746 and improves the explanatory power of the model only marginally.

Two issues are noteworthy. First, in both specifications the effect of Bank marginal costs remains statistically significant and negative. Higher Bank marginal costs significantly reduce the probability that bank $i$ lends via a foreign affiliate in country $j$ at time $t$. An increase in Bank marginal costs by 1 percentage point reduces this likelihood by 4.6 percentage points in the encompassing model in column (5). This magnitude is economically significant in light of the unconditional likelihood of foreign presence of $0.9 \%$ for the full sample (Table 2 ).

Second, conditional on controlling for observable country traits, the specification of country-fixed effects matters for the interpretation of the model. Without country fixed effects, the results in column (4) suggest that less cost-efficient banking markets abroad, as measured by higher Marginal costs abroad, are less likely to experience foreign affiliate entry by German parents whereas Cost leadership is not significant. At the same time, an increase of the average Net interest margin abroad by 1 percentage point increases the probability of foreign presence with 3.2 percentage points, whereas an increase in average Price of capital abroad by 1 percentage point decreases the probability with 2.7 percentage points. So conditional 
on Net interest margin abroad, foreign markets with higher interest rates seem less attractive. But once we control in column (5) for the unobservable country traits that should largely determine foreign market attractiveness, we find the opposite result: Marginal costs abroad exert no significant effect, whereas Cost leadership is significantly positive. Table 2 shows that for around $45 \%$ of all observations, German banks qualify as cost leaders in the various possible host markets, i.e. exhibit Bank marginal costs below average Marginal costs abroad. Cost leadership increases the likelihood of lending abroad via foreign affiliates by 16 basis points. This magnitude is clearly smaller compared to the effect of Bank marginal costs, but still economically significant compared to the unconditional likelihood of foreign presence of $0.9 \%$.

Apparently, the average Price of capital abroad and Net interest margin abroad are better at explaining between country variation, whereas Cost-leadership is better at explaining within-country variation in foreign presence. The first seem to capture whether a particular bank has a cost advantage compared to incumbent banks operating in foreign markets. Cost leadership explains on the basis of the remaining within-country variation if some German banks are more likely to be present than others. This result underpins an important added value of resorting to measures of cost advantage computed from individual bank data, but also other theoretical proxies to explain foreign trade.

Whereas column (5) appears to be a conservative specification that mitigates omitted variable bias the most, we are particularly interested in the relative contribution of the suggested cost advantage proxies to explain foreign affiliate lending activity. Therefore, we remove the cost variables to inspect their explanatory power in column (6). Comparing the pseudo R-squared of the unrestricted model in column (5) to the specification without the cost variables in column (6) suggests that the predictive power of our cost variables is modest. Nonetheless, a formal likelihood ratio test does reject the restricted model. We conclude that cost advantage is of moderate importance to predict foreign affiliate activity more precisely compared to other factors. Against the backdrop of the magnitude of the estimated marginal effect, it represents a source of potentially policy-relevant information.

To further assess the relative importance of observable and unobservable bank-, banking-group, and country-specific effects, we remove the blocks of macro and bank variables in columns (7) and (8). Consider first country fixed effects, which should control for the unobserved heterogeneity that largely determines foreign market attractiveness. A log-likelihood test comparing the specification without country fixed effects in column (4) with the unrestricted model in column (5) shows that the goodness of fit is not statistically better when including country fixed effects. This is confirmed by comparing the specifications in columns (3) and (7), which exclude macro covariates as well. By contrast, the likelihood ratio tests comparing specifications in columns (1) and (7) and those comparing specifications in columns (2) and (7) are both rejected. Hence, in particular bank-specific controls are statistically supported. The role of unobserved country-specific effects seems to be of secondary importance in this sample.

In sum, Cost leadership renders foreign affiliate lending activity more likely. The explanatory power of the preferred model is mostly due to bank-level covariates that explain which banks are active abroad. Whereas the specification of cost advantage proxies cannot be rejected on statistical grounds, their contribution to the explanatory power of the model is modest. However, especially Bank marginal costs at home is economically significant.

\section{Further results and robustness tests}

\subsection{Alternative home and host country efficiency definitions}

Recall that the significantly positive effect of Cost leadership in the preferred specification hinged critically on the specification of country-(fixed) effects, which is sensible in as much this variable then gauges differences in cost advantage of German banks compared to incumbents within each host market.

However, to ensure that we do not fall prey to spurious correlation between this indicator variable and the two other cost variables, we specify in columns (1) and (2) of Table 4 Bank marginal costs and Marginal costs abroad sequentially before replicating our preferred model in column (3). The results confirm the significantly negative effect of home cost advantage. Column (2) corroborates that Marginal costs abroad are irrelevant once we control for a rich set of country-specific factors as well as unobservables.

Next, we scrutinize if the use of average Marginal costs abroad is sensitive to outliers. We show in column (4) a specification using median instead of mean values of bank-level $i$ covariates in each market $j$. Besides our marginal cost estimates, this approach concerns the Net interest margin abroad and the Price of capital abroad. Qualitatively, estimation results are unaffected. In fact, the median Marginal cost abroad is now significantly negative at the $10 \%$-level of significance as well. For all practical purposes the marginal effects of Bank marginal costs and Cost leadership are the same, thereby providing supportive evidence that our main finding is not solely due to very skewed distributions of estimated cost advantage proxies.

In column (5) we acknowledge concerns that our measures are estimated rather than observed. Therefore, we specify an accounting-based performance indicator, the Cost-to-income ratio, that is also used by policy makers (e.g. German Council of Economic Experts, 2013). The effect of German banks' Cost-to-income ratio is also significantly negative. The effect of Cost leadership based on cost-income ratios is not statistically significant. ${ }^{15}$ Overall, these results thus corroborate our main findings.

$\overline{15}$ The effect is significant though when we use median instead of average cost-income ratios. 
Table 4

Alternative proxies for home and host country cost (efficiency).

\begin{tabular}{|c|c|c|c|c|c|c|}
\hline & $(1)$ & $(2)$ & (3) & $(4)$ & $(5)$ & (6) \\
\hline Bank marginal costs $\left(c_{i t}\right)$ & $\begin{array}{l}-0.0652^{* * *} \\
{[0.007]}\end{array}$ & $\begin{array}{l}-0.0652^{* * *} \\
{[0.007]}\end{array}$ & $\begin{array}{l}-0.0458^{* * *} \\
{[0.011]}\end{array}$ & $\begin{array}{l}-0.0405^{* * *} \\
{[0.013]}\end{array}$ & & \\
\hline Marginal costs abroad $\left(c_{j t}\right)$ & & $\begin{array}{l}-0.0001 \\
{[0.005]}\end{array}$ & $\begin{array}{l}-0.0108 \\
{[0.007]}\end{array}$ & & & \\
\hline Cost leadership $\left(I\left(c_{i t}<c_{j t}\right)\right)$ & & & $\begin{array}{l}0.0016^{* * *} \\
{[0.001]}\end{array}$ & & & \\
\hline Return on equity (roe) & $\begin{array}{l}-0.0001^{* * *} \\
{[0.000]}\end{array}$ & $\begin{array}{l}-0.0001^{* * *} \\
{[0.000]}\end{array}$ & $\begin{array}{l}-0.0001^{* * *} \\
{[0.000]}\end{array}$ & $\begin{array}{l}-0.0001^{* * *} \\
{[0.000]}\end{array}$ & $\begin{array}{l}-0.0003^{* * *} \\
{[0.000]}\end{array}$ & $\begin{array}{l}-0.0001^{* * *} \\
{[0.000]}\end{array}$ \\
\hline Z-score $(z s)$ & $\begin{array}{l}-0.0005^{* * *} \\
{[0.000]}\end{array}$ & $\begin{array}{l}-0.0005^{* * *} \\
{[0.000]}\end{array}$ & $\begin{array}{l}-0.0005^{* * *} \\
{[0.000]}\end{array}$ & $\begin{array}{l}-0.0005^{* * *} \\
{[0.000]}\end{array}$ & $\begin{array}{l}-0.0005^{* * *} \\
{[0.000]}\end{array}$ & $\begin{array}{l}-0.0005^{* * *} \\
{[0.000]}\end{array}$ \\
\hline Credit risk $(c r)$ & $\begin{array}{l}-0.0003^{* * *} \\
{[0.000]}\end{array}$ & $\begin{array}{l}-0.0003^{* * *} \\
{[0.000]}\end{array}$ & $\begin{array}{l}-0.0003^{* * *} \\
{[0.000]}\end{array}$ & $\begin{array}{l}-0.0003^{* *} \\
{[0.000]}\end{array}$ & $\begin{array}{l}0.0000 \\
{[0.000]}\end{array}$ & $\begin{array}{l}0.0000 \\
{[0.000]}\end{array}$ \\
\hline Size quintile $(s q)$ & $\begin{array}{l}0.0244^{* * *} \\
{[0.002]}\end{array}$ & $\begin{array}{l}0.0244^{* * *} \\
{[0.002]}\end{array}$ & $\begin{array}{l}0.0244^{* * *} \\
{[0.002]}\end{array}$ & $\begin{array}{l}0.0244^{* * *} \\
{[0.002]}\end{array}$ & $\begin{array}{l}0.0214^{* * *} \\
{[0.002]}\end{array}$ & $\begin{array}{l}0.0240^{* * *} \\
{[0.002]}\end{array}$ \\
\hline Price of capital abroad $\left(r_{j t}^{*}\right)$ & $\begin{array}{l}-0.0006 \\
{[0.003]}\end{array}$ & $\begin{array}{l}-0.0005 \\
{[0.004]}\end{array}$ & $\begin{array}{l}0.0011 \\
{[0.005]}\end{array}$ & & $\begin{array}{l}-0.0002 \\
{[0.003]}\end{array}$ & $\begin{array}{l}0.0038 \\
{[0.007]}\end{array}$ \\
\hline Net interest margin abroad $\left(n_{j t}\right)$ & $\begin{array}{l}-0.0032 \\
{[0.004]}\end{array}$ & $\begin{array}{l}-0.0032 \\
{[0.004]}\end{array}$ & $\begin{array}{l}-0.0028 \\
{[0.005]}\end{array}$ & & $\begin{array}{l}-0.0034 \\
{[0.004]}\end{array}$ & $\begin{array}{l}-0.0049 \\
{[0.004]}\end{array}$ \\
\hline Capital stock $\left(K_{j t}\right)$ & $\begin{array}{l}-0.0003^{* * *} \\
{[0.000]}\end{array}$ & $\begin{array}{l}-0.0003^{* * *} \\
{[0.000]}\end{array}$ & $\begin{array}{l}-0.0003^{* *} \\
{[0.000]}\end{array}$ & $\begin{array}{l}-0.0002^{* *} \\
{[0.000]}\end{array}$ & $\begin{array}{l}-0.0002^{* *} \\
{[0.000]}\end{array}$ & $\begin{array}{l}-0.0002^{* * *} \\
{[0.000]}\end{array}$ \\
\hline Marginal product of capital $\left(M P K_{j t}\right)$ & $\begin{array}{l}0.0087 \\
{[0.007]}\end{array}$ & $\begin{array}{l}0.0087 \\
{[0.007]}\end{array}$ & $\begin{array}{l}0.0082 \\
{[0.006]}\end{array}$ & $\begin{array}{l}0.0083 \\
{[0.006]}\end{array}$ & $\begin{array}{l}0.0085 \\
{[0.006]}\end{array}$ & $\begin{array}{l}0.0087 \\
{[0.007]}\end{array}$ \\
\hline Foreign funding share $\left(\alpha_{j t}\right)$ & $\begin{array}{l}0.0000 \\
{[0.000]}\end{array}$ & $\begin{array}{l}0.0000 \\
{[0.000]}\end{array}$ & $\begin{array}{l}0.0000 \\
{[0.000]}\end{array}$ & $\begin{array}{l}0.0000 \\
{[0.000]}\end{array}$ & $\begin{array}{l}0.0000 \\
{[0.000]}\end{array}$ & $\begin{array}{l}-0.0000 \\
{[0.000]}\end{array}$ \\
\hline Openness foreign market $\left(\beta_{j t}\right)$ & $\begin{array}{l}-0.0001 \\
{[0.003]}\end{array}$ & $\begin{array}{l}-0.0001 \\
{[0.003]}\end{array}$ & $\begin{array}{l}-0.0011 \\
{[0.003]}\end{array}$ & $\begin{array}{l}-0.0015 \\
{[0.003]}\end{array}$ & $\begin{array}{l}-0.0007 \\
{[0.003]}\end{array}$ & $\begin{array}{l}-0.0006 \\
{[0.003]}\end{array}$ \\
\hline Marginal costs abroad median $\left(c_{j t}\right)$ & & & & $\begin{array}{l}-0.0122^{*} \\
{[0.007]}\end{array}$ & & \\
\hline Cost leadership median $\left(I\left(c_{i t}<c_{j t}\right)\right)$ & & & & $\begin{array}{l}0.0022^{* * *} \\
{[0.001]}\end{array}$ & & \\
\hline Price of capital abroad median $\left(r_{j t}^{*}\right)$ & & & & $\begin{array}{l}-0.0040 \\
{[0.007]}\end{array}$ & & \\
\hline Net interest margin abroad median $\left(n_{j t}\right)$ & & & & $\begin{array}{l}-0.0011 \\
{[0.004]}\end{array}$ & & \\
\hline Cost-to-income ratio & & & & & $\begin{array}{l}-0.0003^{* * *} \\
{[0.000]}\end{array}$ & \\
\hline Cost-income ratio abroad $\left(c i_{j t}\right)$ & & & & & $\begin{array}{l}0.0000 \\
{[0.000]}\end{array}$ & \\
\hline Cost leadership cost-income ratio $\left(I\left(c i_{i t}<c i_{j t}\right)\right)$ & & & & & $\begin{array}{l}0.0006 \\
{[0.001]}\end{array}$ & \\
\hline Bank average costs $\left(a c_{i t}\right)$ & & & & & & $\begin{array}{l}-0.1202^{* * *} \\
{[0.015]}\end{array}$ \\
\hline Average costs abroad $\left(a c_{j t}\right)$ & & & & & & $\begin{array}{l}-0.0108 \\
{[0.007]}\end{array}$ \\
\hline Cost leadership average costs $\left(I\left(a c_{i t}<a c_{j t}\right)\right)$ & & & & & & $\begin{array}{l}0.0019^{* * *} \\
{[0.001]}\end{array}$ \\
\hline Observations & 621,746 & 621,746 & 621,746 & 621,746 & 621,746 & 621,746 \\
\hline Observations non-zero & 5473 & 5473 & 5473 & 5473 & 5473 & 5473 \\
\hline Pseudo R-squared & 0.458 & 0.458 & 0.458 & 0.458 & 0.493 & 0.464 \\
\hline
\end{tabular}

Notes: This table reports the marginal effects of estimating the cloglog model in Eq. (1) for the years 2003-2012. The dependent variable is an indicator equal to one if bank $i$ lends to country $j$ through an affiliate at time $t$. All explanatory variables are lagged by one period. All estimations include country fixed effects, year fixed effects, banking group fixed effects Standard errors are clustered at the country level and are reported in brackets. ${ }^{* * *} \mathrm{p}<.01$, ${ }^{* *} \mathrm{p}<.05,{ }^{*} \mathrm{p}<.1$.

Finally, we specify observed average cost of banks to gauge potential cost advantage in column (6). This variable equals observed overhead expenses relative to total assets, where overhead expenses include expenditures for fixed assets, wages, and other administrative expenses. This variable comes close to the empirical proxy employed in Niepmann $(2015,2016){ }^{16}$ One potential shortcoming of average cost measures is that it remains unclear whether overhead costs adequately reflect productivity advantages of financial intermediaries that are captured when estimating marginal costs from a model that emphasizes the efficient allocation of both financial and non-financial "production" factors. ${ }^{17}$ Despite these concerns, the results based on average cost variables confirm those based on marginal cost variables.

\footnotetext{
${ }^{16}$ The measure used to proxy cost efficiency there are overhead cost reported in the Financial Structure Database of the World Bank (Beck et al., 2009). It equals the unweighted average of the ratio of overhead costs to total assets over all banks and is as such also based on micro data.

${ }^{17}$ Especially large banks always exhibit very low average (overhead) cost by construction because financial assets obviously dominate the balance sheet of banks and the share of fixed assets is very low. Whether low average cost do then gauge a better ability to screen and monitor foreign affiliates' projects abroad remains unclear.
} 


\subsection{How to enter which market? Modes and country groups}

So far, we did not distinguish between foreign affiliate lending via subsidiaries and branches. This approach is in line with studies that also analyze data with both types of foreign affiliates jointly (like Focarelli and Pozzolo, 2005; Buch et al., 2014) or simply lack information on foreign branches (such as De Haas and Van Lelyveld, 2010, 2014; Claessens and van Horen, 2014a,b). However, the choice of foreign entry modes is not random. Banks' choices might depend on their business models, the strategic objective of foreign entry, or policies of home and host country regulators based on the trade-off between efficiency and financial stability (Cerutti et al., 2007; Fiechter et al., 2011). Table 5 shows in the first pair of columns a sample split for branches and subsidiaries.

The negative effect of Bank marginal costs on the probability of entry remains significantly negative for both modes of foreign entry, albeit only at the $10 \%$-level for foreign branches. Moreover, the effect is significantly and substantially larger for subsidiaries. This result might suggest that the fixed cost of setting up a subsidiary are even higher compared to those of setting up a foreign branch, for example because of getting chartered and supervised by host country authorities (Fiechter et al., 2011). Consequently, only the very most cost efficient German banks self-select into this mode of foreign entry as also noted in Buch et al. (2014). In contrast, Marginal costs abroad as well as Cost leadership are only significantly different from zero for foreign branches, but not for subsidiaries for which these marginal effects cannot be estimated sufficiently precise.

The next two columns distinguish less developed countries (LDC) according to the World Bank classification. Higher Bank marginal costs reduce the likelihood of operating an affiliate in either type of economy also in this sample. Cost leadership is only significantly positive in the non-LDC sample. This result is inconsistent with literature that finds foreign banks to be only more efficient than domestic banks in LDC (Berger, 2007). The significance of other bank-specific traits remains intact and exhibits similar magnitudes and identical direction of effects in either sample.

Columns (5) and (6) distinguishes EMU from non-EMU member countries. Bank marginal costs do not matter for intraEMU foreign direct investment of German banks. Affiliate activity in EMU countries is more likely for banks that have Cost leadership and where - conditional on being able to compete - foreign markets are more competitive as indicated by the negative effect of Marginal costs abroad. Regarding foreign affiliate activity outside the EMU, however, Cost leadership is not statistically significant. Instead, only those with the lowest Bank marginal costs in the German home market selfselect into these arguably more distant markets. Outside the EMU, the liability of foreignness appears to be so large that only those with low Bank marginal costs can afford operations by means of foreign direct investment in the form of affiliates. Throughout, bank-specific controls exhibit the same effects as for the complete sample.

The distinction between OECD and non-OECD countries in columns (7) and (8) confirms that higher Bank marginal costs reduce the probability to operate affiliates in both OECD and non-OECD countries. But in many respects the results represent a mirror image pattern of LDC and non-LDC results in columns (3) and (4). The magnitude of this effect is statistically significantly larger for non-OECD countries. The larger effect in column (7) mimics the effect of marginal cost on non-LDC countries reported in column (4). Vice versa, the lower magnitude in column (8) for OECD countries corresponds with that for non-LDC countries in column (3). Affiliate activity in developed markets thus seem to require in addition to having low Bank marginal costs at home also Cost leadership. Other bank-specific traits exhibit identical effects as the baseline results.

To further test the robustness of our main results towards the role of financial offshore hosts and financial centers as classified by the Bundesbank. ${ }^{18}$ Excluding either group of countries from the sample does not alter the main effects as shown in columns (9) and (11). Cost leadership does not significantly affect the likelihood of foreign operations in offshore hosts. But it does for financial centers. Interestingly, not having Cost leadership renders it more likely for German banks to operate affiliates in financial centers. Consequently, operations in arguably important hubs of financial intermediation, namely Luxembourg, Switzerland, and the UK, violate our prediction. Instead they might follow very different "strategic" considerations of banks that would lead them to accept a (temporary) cost disadvantage to instead possibly benefit from the opportunities associated with being present in a financial center.

\subsection{Banking groups}

Both the ability and the incentives of different banking groups to engage in and manage international operations may differ systematically. Therefore, Table 6 shows marginal effects for banking pillar subsamples - commercials, savings, and cooperatives - with and without the large banks as defined in Deutsche Bundesbank (2013).

Cost leadership does not significantly explain the presence of international affiliates of commercial banks, even though it does for savings banks and cooperatives. This result may reflect a smaller subsample size, or more activities in Offshore locations and Financial centers that cost advantage captures less well (see Table 5). Regarding bank-specific variables, we confirm that less profitable, more (credit) risky, and larger commercial banks are more likely to operate affiliates.

Surprisingly, savings banks exhibit a positive effect of Bank marginal costs on the probability of being active abroad, while cooperative banks exhibit the same negative Bank marginal costs effect on foreign affiliate probability as for the entire

\footnotetext{
18 Offshore hosts included in the estimation sample are the Philippines, Singapore, and Hong Kong. Included financial centers are Luxembourg, Switzerland, and the United Kingdom.
} 
Table 5

Cost advantage across affiliate type and country groups.

\begin{tabular}{|c|c|c|c|c|c|c|c|c|c|c|c|c|}
\hline & \multicolumn{2}{|c|}{ Affiliate type } & \multicolumn{2}{|c|}{ LDC } & \multicolumn{2}{|c|}{ Euro } & \multicolumn{2}{|c|}{ OECD } & \multicolumn{2}{|c|}{ Offshore } & \multicolumn{2}{|c|}{ Financial center } \\
\hline & $\begin{array}{l}\text { Branch } \\
\text { (1) }\end{array}$ & $\begin{array}{c}\text { Subsidiary } \\
\text { (2) }\end{array}$ & $\begin{array}{l}\text { no } \\
\text { (3) }\end{array}$ & $\begin{array}{l}\text { yes } \\
(4)\end{array}$ & $\begin{array}{l}\text { no } \\
(5)\end{array}$ & $\begin{array}{l}\text { yes } \\
(6)\end{array}$ & $\begin{array}{l}\text { no } \\
\text { (7) }\end{array}$ & $\begin{array}{l}\text { yes } \\
(8)\end{array}$ & $\begin{array}{l}\text { no } \\
(9)\end{array}$ & $\begin{array}{l}\text { yes } \\
(10)\end{array}$ & $\begin{array}{c}\text { no } \\
\text { (11) }\end{array}$ & $\begin{array}{l}\text { yes } \\
(12)\end{array}$ \\
\hline Bank marginal costs $\left(c_{i t}\right)$ & $\begin{array}{l}-0.0167^{*} \\
{[0.009]}\end{array}$ & $\begin{array}{l}-0.0700^{* * *} \\
{[0.009]}\end{array}$ & $\begin{array}{l}-0.0322^{* *} \\
{[0.015]}\end{array}$ & $\begin{array}{l}-0.0632^{* * *} \\
{[0.011]}\end{array}$ & $\begin{array}{l}-0.0614^{* * *} \\
{[0.010]}\end{array}$ & $\begin{array}{l}0.0104 \\
{[0.021]}\end{array}$ & $\begin{array}{l}-0.0583^{* * *} \\
{[0.009]}\end{array}$ & $\begin{array}{l}-0.0299^{*} \\
{[0.017]}\end{array}$ & $\begin{array}{l}-0.0380^{* * *} \\
{[0.011]}\end{array}$ & $\begin{array}{l}-0.1814^{* * *} \\
{[0.016]}\end{array}$ & $\begin{array}{l}-0.0382^{* * *} \\
{[0.011]}\end{array}$ & $\begin{array}{l}-0.2105^{* * *} \\
{[0.034]}\end{array}$ \\
\hline Marginal costs abroad $\left(c_{j t}\right)$ & $\begin{array}{l}-0.0204^{* * *} \\
{[0.008]}\end{array}$ & $\begin{array}{l}-0.0069 \\
{[0.005]}\end{array}$ & $\begin{array}{l}-0.0434^{* * *} \\
{[0.013]}\end{array}$ & $\begin{array}{l}-0.0003 \\
{[0.004]}\end{array}$ & $\begin{array}{l}-0.0039 \\
{[0.006]}\end{array}$ & $\begin{array}{l}-0.0741^{* * *} \\
{[0.028]}\end{array}$ & $\begin{array}{l}-0.0009 \\
{[0.004]}\end{array}$ & $\begin{array}{l}-0.0330^{* *} \\
{[0.014]}\end{array}$ & $\begin{array}{l}-0.0126^{*} \\
{[0.007]}\end{array}$ & $\begin{array}{l}-0.0496^{* *} \\
{[0.021]}\end{array}$ & $\begin{array}{l}-0.0147^{* *} \\
{[0.006]}\end{array}$ & $\begin{array}{l}0.2090^{* * *} \\
{[0.058]}\end{array}$ \\
\hline Cost leadership $\left(I\left(c_{i t}<c_{j t}\right)\right)$ & $\begin{array}{l}0.0023^{* * *} \\
{[0.000]}\end{array}$ & $\begin{array}{l}0.0008 \\
{[0.000]}\end{array}$ & $\begin{array}{l}0.0025^{* * *} \\
{[0.001]}\end{array}$ & $\begin{array}{l}0.0007 \\
{[0.001]}\end{array}$ & $\begin{array}{l}0.0008 \\
{[0.001]}\end{array}$ & $\begin{array}{l}0.0048^{* * *} \\
{[0.001]}\end{array}$ & $\begin{array}{l}0.0008 \\
{[0.001]}\end{array}$ & $\begin{array}{l}0.0028^{* * *} \\
{[0.001]}\end{array}$ & $\begin{array}{l}0.0018^{* * * *} \\
{[0.001]}\end{array}$ & $\begin{array}{l}-0.0028 \\
{[0.003]}\end{array}$ & $\begin{array}{l}0.0020^{* * *} \\
{[0.001]}\end{array}$ & $\begin{array}{l}-0.0067^{* * *} \\
{[0.002]}\end{array}$ \\
\hline Return on equity (roe) & $\begin{array}{l}-0.0001^{* * *} \\
{[0.000]}\end{array}$ & $\begin{array}{l}-0.0001^{* * *} \\
{[0.000]}\end{array}$ & $\begin{array}{l}-0.0002^{* * *} \\
{[0.000]}\end{array}$ & $\begin{array}{l}-0.0001^{* * *} \\
{[0.000]}\end{array}$ & $\begin{array}{l}-0.0001^{* * *} \\
{[0.000]}\end{array}$ & $\begin{array}{l}-0.0002^{* * *} \\
{[0.000]}\end{array}$ & $\begin{array}{l}-0.0001^{* * *} \\
{[0.000]}\end{array}$ & $\begin{array}{l}-0.0002^{* * *} \\
{[0.000]}\end{array}$ & $\begin{array}{l}-0.0001^{* * *} \\
{[0.000]}\end{array}$ & $\begin{array}{l}-0.0001^{* * *} \\
{[0.000]}\end{array}$ & $\begin{array}{l}-0.0001^{* * *} \\
{[0.000]}\end{array}$ & $\begin{array}{l}-0.0002^{* * *} \\
{[0.000]}\end{array}$ \\
\hline Z-score $(z s)$ & $\begin{array}{l}-0.0004^{* * *} \\
{[0.000]}\end{array}$ & $\begin{array}{l}-0.0005^{* * *} \\
{[0.000]}\end{array}$ & $\begin{array}{l}-0.0005^{* * *} \\
{[0.000]}\end{array}$ & $\begin{array}{l}-0.0005^{* * *} \\
{[0.000]}\end{array}$ & $\begin{array}{l}-0.0005^{* * *} \\
{[0.000]}\end{array}$ & $\begin{array}{l}-0.0005^{* * *} \\
{[0.000]}\end{array}$ & $\begin{array}{l}-0.0005^{* * *} \\
{[0.000]}\end{array}$ & $\begin{array}{l}-0.0006^{* * *} \\
{[0.000]}\end{array}$ & $\begin{array}{l}-0.0005^{* * *} \\
{[0.000]}\end{array}$ & $\begin{array}{l}-0.0006^{* * *} \\
{[0.000]}\end{array}$ & $\begin{array}{l}-0.0005^{* * *} \\
{[0.000]}\end{array}$ & $\begin{array}{l}-0.0007^{* * *} \\
{[0.000]}\end{array}$ \\
\hline Credit risk (cr) & $\begin{array}{l}-0.0006^{* * *} \\
{[0.000]}\end{array}$ & $\begin{array}{l}0.0001 \\
{[0.000]}\end{array}$ & $\begin{array}{l}-0.0005^{* * *} \\
{[0.000]}\end{array}$ & $\begin{array}{l}0.0001 \\
{[0.000]}\end{array}$ & $\begin{array}{l}-0.0002^{*} \\
{[0.000]}\end{array}$ & $\begin{array}{l}-0.0005 \\
{[0.000]}\end{array}$ & $\begin{array}{l}-0.0001 \\
{[0.000]}\end{array}$ & $\begin{array}{l}-0.0005^{* *} \\
{[0.000]}\end{array}$ & $\begin{array}{l}-0.0003^{* *} \\
{[0.000]}\end{array}$ & $\begin{array}{l}-0.0008^{*} \\
{[0.000]}\end{array}$ & $\begin{array}{l}-0.0003^{* *} \\
{[0.000]}\end{array}$ & $\begin{array}{l}-0.0002 \\
{[0.000]}\end{array}$ \\
\hline Size quintile $(s q)$ & $\begin{array}{l}0.0158^{* * *} \\
{[0.001]}\end{array}$ & $\begin{array}{l}0.0312^{* * *} \\
{[0.004]}\end{array}$ & $\begin{array}{l}0.0291^{* * *} \\
{[0.002]}\end{array}$ & $\begin{array}{l}0.0162^{* * *} \\
{[0.003]}\end{array}$ & $\begin{array}{l}0.0211^{* * * *} \\
{[0.002]}\end{array}$ & $\begin{array}{l}0.0355^{* * *} \\
{[0.004]}\end{array}$ & $\begin{array}{l}0.0204^{* * *} \\
{[0.003]}\end{array}$ & $\begin{array}{l}0.0309^{* * * *} \\
{[0.002]}\end{array}$ & $\begin{array}{l}0.0245^{* * *} \\
{[0.002]}\end{array}$ & $\begin{array}{l}0.0253^{* * *} \\
{[0.004]}\end{array}$ & $\begin{array}{l}0.0231^{* * *} \\
{[0.002]}\end{array}$ & $\begin{array}{l}0.0458^{* * *} \\
{[0.011]}\end{array}$ \\
\hline Price of capital abroad $\left(r_{j t}^{*}\right)$ & $\begin{array}{l}0.0059 \\
{[0.005]}\end{array}$ & $\begin{array}{l}0.0036 \\
{[0.003]}\end{array}$ & $\begin{array}{l}0.0036 \\
{[0.007]}\end{array}$ & $\begin{array}{l}-0.0013 \\
{[0.003]}\end{array}$ & $\begin{array}{l}0.0009 \\
{[0.004]}\end{array}$ & $\begin{array}{l}-0.0013 \\
{[0.014]}\end{array}$ & $\begin{array}{l}0.0044 \\
{[0.003]}\end{array}$ & $\begin{array}{l}0.0076 \\
{[0.009]}\end{array}$ & $\begin{array}{l}0.0026 \\
{[0.005]}\end{array}$ & $\begin{array}{l}-0.0864^{* * *} \\
{[0.013]}\end{array}$ & $\begin{array}{l}0.0047 \\
{[0.004]}\end{array}$ & $\begin{array}{l}-0.0078 \\
{[0.007]}\end{array}$ \\
\hline Net interest margin abroad $\left(n_{j t}\right)$ & $\begin{array}{l}-0.0002 \\
{[0.004]}\end{array}$ & $\begin{array}{l}-0.0015 \\
{[0.004]}\end{array}$ & $\begin{array}{l}-0.0103^{* *} \\
{[0.004]}\end{array}$ & $\begin{array}{l}0.0013 \\
{[0.002]}\end{array}$ & $\begin{array}{l}-0.0025 \\
{[0.004]}\end{array}$ & $\begin{array}{l}0.0010 \\
{[0.007]}\end{array}$ & $\begin{array}{l}-0.0002 \\
{[0.003]}\end{array}$ & $\begin{array}{l}-0.0124^{* *} \\
{[0.006]}\end{array}$ & $\begin{array}{l}-0.0015 \\
{[0.005]}\end{array}$ & $\begin{array}{l}-0.0080^{* * *} \\
{[0.003]}\end{array}$ & $\begin{array}{l}-0.0017 \\
{[0.004]}\end{array}$ & $\begin{array}{l}-0.0160 \\
{[0.020]}\end{array}$ \\
\hline Capital stock $\left(K_{j t}\right)$ & $\begin{array}{l}-0.0001 \\
{[0.000]}\end{array}$ & $\begin{array}{l}-0.0002^{* * *} \\
{[0.000]}\end{array}$ & $\begin{array}{l}-0.0004^{* * *} \\
{[0.000]}\end{array}$ & $\begin{array}{l}-0.0001 \\
{[0.000]}\end{array}$ & $\begin{array}{l}-0.0003^{* * *} \\
{[0.000]}\end{array}$ & $\begin{array}{l}0.0004 \\
{[0.001]}\end{array}$ & $\begin{array}{l}-0.0001 \\
{[0.000]}\end{array}$ & $\begin{array}{l}-0.0005^{* * *} \\
{[0.000]}\end{array}$ & $\begin{array}{l}-0.0003^{* *} \\
{[0.000]}\end{array}$ & $\begin{array}{l}0.0029 \\
{[0.011]}\end{array}$ & $\begin{array}{l}-0.0003^{* *} \\
{[0.000]}\end{array}$ & $\begin{array}{l}-0.0007 \\
{[0.002]}\end{array}$ \\
\hline Marginal product of capital $\left(M P K_{j t}\right)$ & $\begin{array}{l}0.0023 \\
{[0.005]}\end{array}$ & $\begin{array}{l}0.0062 \\
{[0.005]}\end{array}$ & $\begin{array}{l}0.0143^{* *} \\
{[0.007]}\end{array}$ & $\begin{array}{l}-0.0001 \\
{[0.006]}\end{array}$ & $\begin{array}{l}0.0072 \\
{[0.007]}\end{array}$ & $\begin{array}{l}0.0083 \\
{[0.010]}\end{array}$ & $\begin{array}{l}0.0039 \\
{[0.006]}\end{array}$ & $\begin{array}{l}0.0092 \\
{[0.010]}\end{array}$ & $\begin{array}{l}0.0080 \\
{[0.007]}\end{array}$ & $\begin{array}{l}-0.0036 \\
{[0.023]}\end{array}$ & $\begin{array}{l}0.0106^{*} \\
{[0.006]}\end{array}$ & $\begin{array}{l}0.0010 \\
{[0.014]}\end{array}$ \\
\hline Foreign funding share $\left(\alpha_{j t}\right)$ & $\begin{array}{l}0.0002 \\
{[0.000]}\end{array}$ & $\begin{array}{l}-0.0000 \\
{[0.000]}\end{array}$ & $\begin{array}{l}0.0001 \\
{[0.000]}\end{array}$ & $\begin{array}{l}-0.0002 \\
{[0.000]}\end{array}$ & $\begin{array}{l}-0.0001 \\
{[0.000]}\end{array}$ & $\begin{array}{l}0.0002 \\
{[0.000]}\end{array}$ & $\begin{array}{l}-0.0004 \\
{[0.000]}\end{array}$ & $\begin{array}{l}0.0004 \\
{[0.000]}\end{array}$ & $\begin{array}{l}0.0001 \\
{[0.000]}\end{array}$ & $\begin{array}{l}0.0007 \\
{[0.001]}\end{array}$ & $\begin{array}{l}-0.0000 \\
{[0.000]}\end{array}$ & $\begin{array}{l}-0.0018^{* * *} \\
{[0.001]}\end{array}$ \\
\hline Openness foreign market $\left(\beta_{j t}\right)$ & $\begin{array}{l}-0.0026 \\
{[0.003]}\end{array}$ & $\begin{array}{l}0.0002 \\
{[0.002]}\end{array}$ & $\begin{array}{l}-0.0019 \\
{[0.004]}\end{array}$ & $\begin{array}{l}0.0009 \\
{[0.003]}\end{array}$ & $\begin{array}{l}0.0005 \\
{[0.003]}\end{array}$ & $\begin{array}{l}-0.0101 \\
{[0.007]}\end{array}$ & $\begin{array}{l}-0.0021 \\
{[0.002]}\end{array}$ & $\begin{array}{l}0.0016 \\
{[0.006]}\end{array}$ & $\begin{array}{l}-0.0012 \\
{[0.003]}\end{array}$ & $\begin{array}{l}0.0349 \\
{[0.023]}\end{array}$ & $\begin{array}{l}-0.0018 \\
{[0.003]}\end{array}$ & $\begin{array}{l}0.0090 \\
{[0.015]}\end{array}$ \\
\hline Observations & 606,772 & 613,566 & 396,071 & 224,640 & 470,699 & 150,012 & 299,483 & 321,228 & 583,895 & 36,816 & 583,895 & 36,816 \\
\hline Observations non-zero & 3798 & 3867 & 4228 & 1239 & 3404 & 2063 & 1596 & 3871 & 5062 & 405 & 4810 & 657 \\
\hline Pseudo R-squared & 0.439 & 0.478 & 0.456 & 0.461 & 0.458 & 0.455 & 0.471 & 0.450 & 0.459 & 0.445 & 0.457 & 0.457 \\
\hline Number of banks & 1600 & 1600 & 1600 & 1600 & 1600 & 1600 & 1600 & 1600 & 1600 & 1600 & 1600 & 1600 \\
\hline Number of countries & 58 & 59 & 36 & 23 & 48 & 13 & 32 & 29 & 56 & 3 & 56 & 3 \\
\hline
\end{tabular}

Notes: This table reports the marginal effects of estimating the cloglog model in Eq. (1) for the years 2003-2012. Affiliate type indicates estimations in which the dependent variable is defined in terms of foreign presence of either branches or subsidiaries. LDC indicates less developed countries as defined by the World Bank. Euro countries are members of the European Monetary Union as of the respective admission data. OECD indicates sample splits for member countries of the Organization of Economic Cooperation and Development. Offshore and financial center countries contained in the estimation sample are classified following the Bundesbank. The former are the Philippines, Singapore, and Switzerland. The latter are Luxembourg, Switzerland, and the United Kingdom. The dependent variable is an indicator equal to one if bank $i$ lends to country $j$ through an affiliate at time $t$. All explanatory variables are lagged by one period. We include but do not report country, year, and banking group fixed effects. Standard errors are clustered at the country level and are reported in brackets. ${ }^{* * *} \mathrm{p}<.01,{ }^{* *} \mathrm{p}<.05,{ }^{*} \mathrm{p}<.1$ 
Table 6

Foreign affiliate activity across banking groups.

\begin{tabular}{|c|c|c|c|c|c|c|c|}
\hline & $\begin{array}{c}\text { Commercials } \\
\text { (1) }\end{array}$ & $\begin{array}{c}\text { Savings } \\
\text { (2) }\end{array}$ & $\begin{array}{c}\text { Cooperatives } \\
\text { (3) }\end{array}$ & $\begin{array}{c}\text { Large } \\
\text { commercials } \\
(4)\end{array}$ & $\begin{array}{l}\text { Large } \\
\text { savings } \\
\text { (5) }\end{array}$ & $\begin{array}{c}\text { Large } \\
\text { cooperatives } \\
\text { (6) }\end{array}$ & $\begin{array}{c}\text { Small } \\
\text { banks } \\
(7)\end{array}$ \\
\hline Bank marginal costs $\left(c_{i t}\right)$ & $\begin{array}{l}-0.5141^{* * *} \\
{[0.116]}\end{array}$ & $\begin{array}{l}0.8331^{* * *} \\
{[0.040]}\end{array}$ & $\begin{array}{l}-0.1879^{* * *} \\
{[0.022]}\end{array}$ & $\begin{array}{l}-11.0637^{* * *} \\
{[1.482]}\end{array}$ & $\begin{array}{l}4.5996^{* * *} \\
{[0.573]}\end{array}$ & $\begin{array}{l}-53.6861^{* * *} \\
{[10.325]}\end{array}$ & $\begin{array}{l}-0.0017 \\
{[0.006]}\end{array}$ \\
\hline Marginal costs abroad $\left(c_{j t}\right)$ & $\begin{array}{l}-0.0064 \\
{[0.084]}\end{array}$ & $\begin{array}{l}-0.0354 \\
{[0.024]}\end{array}$ & $\begin{array}{l}0.0021 \\
{[0.002]}\end{array}$ & $\begin{array}{l}-0.5286 \\
{[0.367]}\end{array}$ & $\begin{array}{l}0.3212 \\
{[0.295]}\end{array}$ & $\begin{array}{l}0.9026 \\
{[0.619]}\end{array}$ & $\begin{array}{l}0.0012 \\
{[0.004]}\end{array}$ \\
\hline Cost leadership $\left(I\left(c_{i t}<c_{j t}\right)\right)$ & $\begin{array}{l}-0.0088 \\
{[0.008]}\end{array}$ & $\begin{array}{l}0.0070^{* * *} \\
{[0.002]}\end{array}$ & $\begin{array}{l}0.0004^{* *} \\
{[0.000]}\end{array}$ & $\begin{array}{l}0.0446^{* *} \\
{[0.019]}\end{array}$ & $\begin{array}{l}-0.0100 \\
{[0.023]}\end{array}$ & $\begin{array}{l}0.0338 \\
{[0.034]}\end{array}$ & $\begin{array}{l}-0.0003 \\
{[0.000]}\end{array}$ \\
\hline Return on equity (roe) & $\begin{array}{l}-0.0020^{* * *} \\
{[0.000]}\end{array}$ & $\begin{array}{l}-0.0002^{* * *} \\
{[0.000]}\end{array}$ & $\begin{array}{l}-0.0002^{* * *} \\
{[0.000]}\end{array}$ & $\begin{array}{l}-0.0072^{* * *} \\
{[0.000]}\end{array}$ & $\begin{array}{l}-0.0076^{* * *} \\
{[0.001]}\end{array}$ & $\begin{array}{l}0.0253^{* * *} \\
{[0.003]}\end{array}$ & $\begin{array}{l}-0.0000^{* * *} \\
{[0.000]}\end{array}$ \\
\hline Z-score $(z s)$ & $\begin{array}{l}-0.0014^{* * *} \\
{[0.000]}\end{array}$ & $\begin{array}{l}-0.0033^{* * *} \\
{[0.000]}\end{array}$ & $\begin{array}{l}-0.0001^{* * *} \\
{[0.000]}\end{array}$ & $\begin{array}{l}-0.0070^{* * *} \\
{[0.001]}\end{array}$ & $\begin{array}{l}-0.0094^{* * *} \\
{[0.001]}\end{array}$ & $\begin{array}{l}-0.0171^{* *} \\
{[0.007]}\end{array}$ & $\begin{array}{l}-0.0001^{* * *} \\
{[0.000]}\end{array}$ \\
\hline Credit risk $(\mathrm{cr})$ & $\begin{array}{l}0.0077^{* * *} \\
{[0.001]}\end{array}$ & $\begin{array}{l}-0.0133^{* * *} \\
{[0.001]}\end{array}$ & $\begin{array}{l}0.0008^{* * *} \\
{[0.000]}\end{array}$ & $\begin{array}{l}0.2913^{* * *} \\
{[0.010]}\end{array}$ & $\begin{array}{l}0.0443^{\text {*** }} \\
{[0.009]}\end{array}$ & $\begin{array}{l}0.0178 \\
{[0.020]}\end{array}$ & $\begin{array}{l}-0.0002^{* *} \\
{[0.000]}\end{array}$ \\
\hline Size quintile $(s q)$ & $\begin{array}{l}0.1973^{* * *} \\
{[0.021]}\end{array}$ & & $\begin{array}{l}0.0043^{* * *} \\
{[0.001]}\end{array}$ & & & & $\begin{array}{l}0.0057^{* * *} \\
{[0.000]}\end{array}$ \\
\hline Price of capital abroad $\left(r_{j t}^{*}\right)$ & $\begin{array}{l}0.0189 \\
{[0.047]}\end{array}$ & $\begin{array}{l}0.0027 \\
{[0.021]}\end{array}$ & $\begin{array}{l}-0.0020 \\
{[0.002]}\end{array}$ & $\begin{array}{l}0.4314 \\
{[0.266]}\end{array}$ & $\begin{array}{l}-0.0125 \\
{[0.286]}\end{array}$ & $\begin{array}{l}-0.8880^{*} \\
{[0.514]}\end{array}$ & $\begin{array}{l}-0.0009 \\
{[0.004]}\end{array}$ \\
\hline Net interest margin abroad $\left(n_{j t}\right)$ & $\begin{array}{l}-0.0327 \\
{[0.044]}\end{array}$ & $\begin{array}{l}-0.0081 \\
{[0.021]}\end{array}$ & $\begin{array}{l}0.0003 \\
{[0.001]}\end{array}$ & $\begin{array}{l}-0.4972^{* *} \\
{[0.212]}\end{array}$ & $\begin{array}{l}-0.2533 \\
{[0.266]}\end{array}$ & $\begin{array}{l}0.3316 \\
{[0.336]}\end{array}$ & $\begin{array}{l}0.0031 \\
{[0.002]}\end{array}$ \\
\hline Capital stock $\left(K_{j t}\right)$ & $\begin{array}{l}-0.0021^{* *} \\
{[0.001]}\end{array}$ & $\begin{array}{l}-0.0011 \\
{[0.001]}\end{array}$ & $\begin{array}{l}-0.0001^{* *} \\
{[0.000]}\end{array}$ & $\begin{array}{l}0.0033 \\
{[0.007]}\end{array}$ & $\begin{array}{l}-0.0146 \\
{[0.012]}\end{array}$ & $\begin{array}{l}-0.0258 \\
{[0.017]}\end{array}$ & $\begin{array}{l}-0.0002^{* *} \\
{[0.000]}\end{array}$ \\
\hline $\begin{array}{l}\text { Marginal product of capital } \\
\qquad\left(M P K_{j t}\right)\end{array}$ & 0.0838 & 0.0417 & $\begin{array}{l}-0.0018 \\
{[0.003]}\end{array}$ & 0.1635 & 0.6141 & $\begin{array}{l}-0.6156 \\
{[0.698]}\end{array}$ & $\begin{array}{l}0.0048 \\
{[0.005]}\end{array}$ \\
\hline Foreign funding share $\left(\alpha_{j t}\right)$ & $\begin{array}{l}0.0031 \\
{[0.003]}\end{array}$ & $\begin{array}{l}-0.0013 \\
{[0.001]}\end{array}$ & $\begin{array}{l}-0.0003 \\
{[0.000]}\end{array}$ & $\begin{array}{l}-0.0141 \\
{[0.021]}\end{array}$ & $\begin{array}{l}-0.0161 \\
{[0.016]}\end{array}$ & $\begin{array}{l}-0.0377 \\
{[0.057]}\end{array}$ & $\begin{array}{l}0.0001 \\
{[0.000]}\end{array}$ \\
\hline Openness foreign market $\left(\beta_{j t}\right)$ & $\begin{array}{l}-0.0770^{* *} \\
{[0.037]}\end{array}$ & $\begin{array}{l}0.0295^{*} \\
{[0.015]}\end{array}$ & $\begin{array}{l}0.0003 \\
{[0.001]}\end{array}$ & $\begin{array}{l}-0.3305^{* *} \\
{[0.149]}\end{array}$ & $\begin{array}{l}0.3510^{*} \\
{[0.197]}\end{array}$ & $\begin{array}{l}-0.2925 \\
{[0.252]}\end{array}$ & $\begin{array}{l}0.0014 \\
{[0.003]}\end{array}$ \\
\hline Observations & 36,055 & 81,919 & 349,653 & 4180 & 4075 & 932 & 612,455 \\
\hline Observations non-zero & 3274 & 1706 & 493 & 1956 & 1621 & 452 & 1444 \\
\hline Pseudo R-squared & 0.286 & 0.461 & 0.680 & 0.278 & 0.249 & 0.694 & 0.309 \\
\hline Number of banks & 111 & 210 & 1023 & 10 & 11 & 2 & 1578 \\
\hline Number of countries & 59 & 58 & 52 & 59 & 58 & 52 & 59 \\
\hline
\end{tabular}

Notes: This table reports the marginal effects of estimating the cloglog model in Eq. (1) for the years 2003-2012. Banking groups are defined as in Deutsche Bundesbank (2013) according to large and small banks within each of the three pillars commercial, savings, and cooperative banks. The dependent variable is an indicator equal to one if bank $i$ lends to country $j$ through an affiliate at time $t$. All explanatory variables are lagged by one period. We include but do not report country, year, and banking group fixed effects. Standard errors are clustered at the country level and are reported in brackets. ${ }^{*} p<.01,{ }^{* *} \mathrm{p}<.05$, ${ }^{*} \mathrm{p}<.1$.

sample. Apparently, within the savings bank sector it is not the low-cost banks that venture abroad. Cost leadership among cooperatives and savings exhibits, in turn, a significant influence on the likelihood of affiliations abroad. Bank-specific covariates highlight further differences across banking pillars regarding the likelihood of operating foreign affiliates. Across all groups, less profitable banks, banks with higher insolvency risk, and larger banks are more likely to internationalize. ${ }^{19}$ Foreign presence is more likely for credit risky commercial banks and cooperatives, while it is less likely for savings banks.

Within each pillar, the Deutsche Bundesbank (2013) distinguishes large and smaller peers, for instance the Landesbanken compared to regional savings banks. The next three columns of Table 6 show marginal effect estimates for the large banks per pillar only. The effects on German Bank marginal costs confirm the results shown in columns (1)-(3), which illustrates the dominance of relatively few very large banks in terms of foreign activity observations in the ijt-sample.

Among large commercial banks, Cost leadership is significant. In contrast, for both large savings banks and large cooperative Cost leadership is not statistically significant. Note that the number of banks within large banking groups-especially within large cooperatives-is very small, which might bias inference. In Column (7) we include a specification in which we exclude all large banks. For this group of small banks only, we no longer find any significant results on the cost variables, even though the other bank controls exhibit similar sign and significance as in the full sample. Thereby, we confirm that foreign affiliate lending is largely a matter of very large banks in general (Buch et al., 2014) and probably a matter of groupinternal cross-border activity in particular (see, for example, Box 1 in Central Bank, 2016).

\subsection{On the importance of bank size}

A number of results discussed so far raise two important concerns related to the size of banks. First, it remains unclear whether foreign affiliate lending activity is really co-determined by the suggested measures of cost advantage or rather a

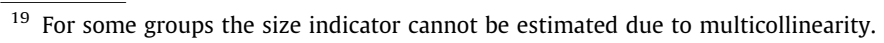


consequence of not measuring the size of banks adequately. To this end, Table C.3 in Appendix C replaces the Size quintile (sq) indicator in the spirit of Aviat and Coeurdacier (2007) with several alternative size proxies. Given the well-known, very skewed distribution of parent bank size, we winsorize all proxies by setting the 10 largest observations equal to the 11th largest observation in each year. ${ }^{20}$ We begin in column (1) by including Total assets as a size proxy. The positive effect of Cost leadership is no longer statistically different from zero. When we include gross loans, which is highly correlated with total assets ( $\rho=0.95)$, Cost leadership is significant, although the coefficient is smaller compared to the results reported so far. Fixed assets and the Number of employees in columns (3) and (4) also confirm the main results.

But given the overall modest contribution to the explained variation in observed foreign affiliate activities, an alternative economic narrative might simply be that foreign affiliate activities are driven by just very few players that venture into key markets for totally different but cost advantage reasons. Therefore, we test in Table C.4 the sensitivity of our results when excluding sequentially the largest banks in the largest markets. Column (1) excludes the 20 largest countries in terms of German banks' total loans. We continue to find that the relative sorting at home on grounds of Bank marginal costs exhibits a significant effect. Even after German banks self-selected into the largest foreign markets, having low Bank marginal costs at home appears to be still relevant to guide choices on where to set-up foreign operations. We also find that Marginal costs abroad remains statistically significant. If German banks are more cost efficient compared to the average incumbent, they are more likely to operate an affiliate even in these smaller markets.

In column (2) we exclude the five largest banks based on median total assets over the sample period. The marginal effects for both Bank marginal cost as well as Marginal costs abroad are insignificant. Especially the former results underscores the very skewed distribution of cost advantage at home where only fairly few, very large players determine domestic advantage. Nonetheless, we do find that more than just the top five German banks are able to undercut the marginal cost of incumbent banks abroad, because Cost leadership is still positive and significant. In a way, this big-fish-small-pond effect might merely mean that even the second-tier banks in a fairly well-developed financial system might be cost leaders when operating in less developed financial systems (Berger, 2007).

In columns (3) and (4) we present results for two alternative definitions of large markets, namely median GDP and median GDP per capita. In both cases, GDP is measured in constant 2005 prices and we exclude the largest 20 countries. All results confirm those reported in column (1) and thus the baseline shown in the paper.

\section{Conclusion}

We distinguish two types of cost advantage to test their relative importance to explain foreign bank affiliate activity: the marginal costs of banks in home markets and the average marginal costs faced in foreign markets. Thereby, we complement existing literature on international banking theory with an empirical foundation of cost advantage based on individual bank data that permits to quantify its importance relative to other bank- and country-specific explanatory factors. To this end, we employ a rich sample provided by the Research Data Service Center of Deutsche Bundesbank, which is comprised of all 1600 universal German banks that are both internationally active and inactive between 2003 and 2012. We combine bank-level information on international affiliate lending with public micro data of local competitors in 59 potential host markets.

Our main result is that banks are more likely to operate affiliates in foreign markets if they have low marginal cost in the home market. This result therefore corroborates Melitz-type of modern trade theories and it complements existing empirical evidence on the intensive margin of cross-border and foreign affiliate lending. We also find that banks are more likely to operate affiliates if they exhibit cost leadership in terms of their marginal cost relative to host market incumbents. This result therefore underscores the different types of benchmarks that constitute different types of cost advantage. The finding gives rise to potential big-fish-in-small-pond effects to the extent that even the second tier of banks in terms of cost efficiency might still be good enough to compete with banks in markets with even worse institutions.

The economic magnitude of bank marginal costs is not negligible. A reduction of bank marginal costs by 1 percentage point increases the likelihood to operate foreign affiliates by 4.6 percentage points. Having cost leadership in host markets further increases the likelihood by 0.16 percentage points. Given an unconditional probability of foreign affiliate lending on the order of 0.9 percentage points, the economic magnitude of these effects is relevant. However, we also find that the contribution of these cost advantage proxies to the explained variation of observed foreign affiliate activity is fairly small. Especially the specification of bank-specific controls and fixed effects for unobservable banking group and, to a lesser extent, country traits are more important in this regard. We find that banks, which are less profitable, exhibit larger insolvency and lower credit risk, and that are larger exhibit a higher likelihood of operating affiliates abroad. Because formal testing rejects the exclusion of cost advantage factors, we conclude that these results underline the importance of both cost advantage as well as risk and return traits specific to financial firms to explain internationalization choices in banking.

\footnotetext{
${ }^{20}$ Irrespective of taking logs or not, the data otherwise largely reflects an indicator variable whether an observation belongs to the very largest banks or not given the numerical range of total assets and other continuous variables. If we do not exclude the ten largest banks, all results still hold though except for the log-level of gross total assets.
} 
A number of additional results emerge. Separating the foreign entry with subsidiaries versus branches confirms the importance of cost advantage proxies after controlling for bank-specific risk traits. However, differences regarding the significance of cost effects and selected bank-specific traits suggest that future research on the type of business models pursued by different internationalization modes is warranted.

Cost leadership and bank marginal costs at home are of particular importance when host markets are comparable to the German home market. The baseline effects are amplified in OECD, developed countries, and markets in the European Monetary Union. Cost leadership does not play a role for affiliates in financial centers and offshore locations. If anything, there is a negative effect of cost leadership on the probability of presence in these locations.

The empirical results highlight significant differences across so-called banking pillars. Especially large savings banks appear to operate foreign affiliates irrespective of high domestic marginal cost. Having low bank marginal costs at home plays mostly a role for large commercial banks, but also for savings and cooperative banks.

Finally, the baseline results are also robust towards the use of different cost proxies, different size proxies, and the exclusion of the largest banks and the most significant countries from the sample.

\section{Appendix A. Estimating marginal costs}

To specify a cost function, we follow the intermediation approach Sealey and Lindley (1977). Banks demand three factors (deposits, labor, and physical capital) in complete factor markets at prices $w_{\text {pit }}$, where $p=1,2,3$, to generate three outputs $y_{\text {qit }}$, where $q=1,2,3$ (securities, loans and off-balance sheet activities). We also include a vector of covariates $z_{i t}$ to adjust for differences in relative risk and performance described below. A translog total cost function for bank $i$ at time $t$ including a time trend $T$ is:

$$
\begin{aligned}
\log \text { TOC }_{i t}= & \alpha+\sum_{p=1}^{3} \beta_{p} \log w_{p i t}+\sum_{q=1}^{3} \beta_{q} \log y_{q i t}+\delta \log \left(z_{i t}\right)+\sum_{p=1}^{3}(\zeta / 2)\left(\log w_{p i t}\right)^{2}+\sum_{p<k} \sum \eta_{p k} \log w_{p i t} \log w_{k i t} \\
& +\sum_{q=1}^{3}(\theta / 2)\left(\log y_{q i t}\right)^{2}+\sum_{q<l} \sum \eta_{q l} \log y_{q i t} \log y_{\text {lit }}+\sum_{p=1}^{3} \sum_{q=1}^{3} \lambda_{p q} \log w_{p i t} \log y_{q i t}+\sum_{k=1}^{2} v_{k} T^{k}+\sum_{p=1}^{3} \xi_{p} \log w_{p i t} T \\
& +\sum_{p=1}^{3} \omega_{q} \log y_{q i t} T+\varepsilon_{i t},
\end{aligned}
$$

We impose homogeneity of degree one on input prices and assume that production technologies are identical across banks. This approach permits a comparison of marginal costs. Given parameter estimates of Eq. (2), we calculate the marginal costs for each bank $i$ in country $j$ as the sum of partial cost derivatives of Eq. (2) with respect to the three outputs:

$$
c_{i t}=\sum_{q=1}^{3} \frac{T O C_{q i j t}}{y_{q i j t}} \frac{\partial \log T O C}{\partial \log y_{q i j t}} .
$$

Cost function variables are defined as follows. Total operating cost TOC cover all operating expenses of the bank including interest expenses. We obtain total bank revenues by adding profits before tax PBT. The price of fixed assets $w_{1}$ is the ratio of expenses for fixed assets to fixed assets. The cost of labor $w_{2}$ equals the ratio of personnel expenses to the total number of employees. Funding costs are approximated by the ratio of interest expenses to total deposits. We specify three outputs: securities $\left(y_{1}\right)$, gross loans $\left(y_{2}\right)$ and off-balance sheet activities $\left(y_{3}\right)$.

The vector of risk and return controls $z_{i t}$ is important in at least two ways. First, banks that have superior productivity could have lower marginal costs because they are better able to manage risk. Second, risk motives, like diversification, could be important to determine banks' decisions to operate in foreign host markets.

Therefore, we first follow Mester (1996) and include equity. To adjust for differences in risk-adjusted performance, we include two risk proxies: credit risk is measured as loan impairment charges over gross loans and the $z$-score, which measures insolvency risk (Laeven and Levine, 2009). It equals is the sum of return on assets (RoA) and the capital ratio (Equity/total assets, TA) divided by the standard deviation of return on assets over the sample period. Z-scores reflect the number of standard deviations that a bank's RoA must fall below its expected value before equity is depleted. Lower z-scores therefore indicate riskier banks. We use two relative performance measures: the cost-to-income ratio is the sum of personnel expenses and other operating expenses over total revenues, and return on equity is pre-impairment operating profit divided by equity. Finally we follow the example of Aviat and Coeurdacier (2007) and specify a quintile indicator to measure bank size. We allocate banks to one of five groups based on the distribution of total assets at home in each year.

Table A.1 summarizes cost and profit frontier variables, separating German (home) banks from host market bank data. Note that we exclude the subsidiaries of German banks that are active in foreign markets $j$ when estimating Eq. (2) so as to obtain measures of foreign markets' bank efficiency scores net off the performance of German banks. 
Table A.1

Summary statistics marginal cost and price estimation.

\begin{tabular}{|c|c|c|c|c|c|}
\hline Full sample & Mean & SD & p5 & p95 & $\mathrm{N}$ \\
\hline$y_{1}$ (in millions) & 840.57 & 13986.95 & 0.94 & 960.15 & 133,204 \\
\hline$y_{2}$ (in millions) & 1458.48 & 13298.97 & 10.52 & 2888.20 & 133,204 \\
\hline$y_{3}$ (in millions) & 987.44 & 20695.38 & 0.39 & 584.10 & 133,204 \\
\hline$w_{1}($ in $\%)$ & 205.40 & 450.12 & 33.40 & 682.01 & 133,204 \\
\hline$w_{2}$ (in thousands) & 54.45 & 21.67 & 30.03 & 92.67 & 133,204 \\
\hline$w_{3}($ in $\%)$ & 2.13 & 1.27 & 0.46 & 4.24 & 133,204 \\
\hline $\mathrm{Z}$ (in millions) & 205.86 & 2171.37 & 2.41 & 401.72 & 133,204 \\
\hline TOC (in millions) & 125.05 & 1236.82 & 1.06 & 243.55 & 133,204 \\
\hline PBT (in millions) & 31.55 & 377.52 & -0.13 & 61.43 & 133,204 \\
\hline $\operatorname{cr}($ in $\%)$ & 0.58 & 0.94 & -0.01 & 2.27 & 133,204 \\
\hline cit (in \%) & 52.84 & 19.59 & 27.82 & 84.01 & 133,204 \\
\hline zS & 34.92 & 24.65 & 6.42 & 82.82 & 133,204 \\
\hline roe (in \%) & 12.62 & 9.48 & -1.84 & 27.38 & 133,204 \\
\hline Assets (in millions) & 3053.56 & 34405.85 & 22.28 & 4993.01 & 133,204 \\
\hline \multicolumn{6}{|l|}{ Germany } \\
\hline$y_{1}$ (in millions) & 1538.93 & 20112.46 & 9.88 & 1723.11 & 16,892 \\
\hline$y_{2}$ (in millions) & 2110.78 & 14440.06 & 32.43 & 4000.82 & 16,892 \\
\hline$y_{3}$ (in millions) & 609.99 & 6309.49 & 1.96 & 465.15 & 16,892 \\
\hline$w_{1}($ in $\%)$ & 148.03 & 356.53 & 37.03 & 475.00 & 16,892 \\
\hline$w_{2}$ (in thousands) & 58.12 & 17.50 & 41.63 & 90.00 & 16,892 \\
\hline$w_{3}($ in $\%)$ & 2.44 & 0.98 & 1.10 & 3.76 & 16,892 \\
\hline $\mathrm{Z}$ (in millions) & 190.69 & 1195.10 & 5.00 & 394.33 & 16,892 \\
\hline TOC (in millions) & 211.58 & 1557.63 & 2.99 & 320.17 & 16,892 \\
\hline PBT (in millions) & 24.42 & 178.25 & 0.50 & 60.90 & 16,892 \\
\hline cr (in \%) & 0.69 & 0.91 & -0.91 & 2.08 & 16,892 \\
\hline cit (in \%) & 44.15 & 10.93 & 26.62 & 58.92 & 16,892 \\
\hline ZS & 35.36 & 18.10 & 13.18 & 66.94 & 16,892 \\
\hline roe (in \%) & 15.43 & 6.96 & 6.28 & 26.81 & 16,892 \\
\hline Assets (in millions) & 5206.13 & 48929.08 & 66.23 & 6917.87 & 16,892 \\
\hline \multicolumn{6}{|l|}{ All other countries } \\
\hline$y_{1}$ (in millions) & 739.14 & 12853.86 & 0.75 & 757.17 & 116,312 \\
\hline$y_{2}$ (in millions) & 1363.74 & 13122.37 & 9.77 & 2672.81 & 116,312 \\
\hline$y_{3}$ (in millions) & 1042.26 & 22015.81 & 0.32 & 608.89 & 116,312 \\
\hline$w_{1}($ in $\%)$ & 213.73 & 461.55 & 32.78 & 706.25 & 116,312 \\
\hline$w_{2}$ (in thousands) & 53.92 & 22.16 & 29.08 & 93.05 & 116,312 \\
\hline$w_{3}($ in $\%)$ & 2.08 & 1.29 & 0.43 & 4.31 & 116,312 \\
\hline $\mathrm{Z}$ (in millions) & 208.06 & 2278.62 & 2.27 & 403.29 & 116,312 \\
\hline TOC (in millions) & 112.48 & 1182.50 & 1.00 & 226.49 & 116,312 \\
\hline PBT (in millions) & 32.59 & 398.24 & -0.22 & 61.50 & 116,312 \\
\hline $\mathrm{cr}$ (in \%) & 0.56 & 0.94 & 0.00 & 2.31 & 116,312 \\
\hline cit (in \%) & 54.10 & 20.24 & 27.96 & 86.28 & 116,312 \\
\hline Zs & 34.86 & 25.46 & 6.09 & 84.89 & 116,312 \\
\hline roe (in \%) & 12.21 & 9.72 & -2.85 & 27.51 & 116,312 \\
\hline Assets (in millions) & 2740.94 & 31737.05 & 20.83 & 4513.49 & 116,312 \\
\hline
\end{tabular}

Notes: This table represent summary statistics for the estimation of marginal costs and prices. SD indicates standard deviation, $\mathrm{N}$ indicates the number of observations and p5 and p95 are the 5th and 95th percentile, respectively. We estimate a single world cost frontier. All data are from Bankscope.

\section{Appendix B. Sample construction}

To estimate Eq. (1), we match affiliate data on Loans and advances with macro and parent bank data. To account for the self-selection of banks into host markets based on cost advantage, we do not constrain the set of potential foreign markets ex ante so that German banks can set up affiliates in any country $j$.

We start with Bundesbank identifiers that show 2258 domestic German banks exist during our sample period. Matching these identifiers to foreign activity data from the the External position of banks data (AUSTA "Auslandsstatus") shows that 76 out of 2258 banks are at some point in time present in at least one of 114 countries. Of the 2258 Bundesbank identifiers, we can match 1767 to Bankscope data. Out of these, 68 banks are active abroad in 114 countries. Non-matched banks are typically very small.

We "rectangularize" the panel in each year (2002-2012), such that each bank could possibly be active in each country in the AUSTA in each year. First, the rectangularized data comprise 114 countries to which 1767 German banks had at least once an exposure over the years 2002-2012 for a total number of 1,795,840 observations in the ijt panel.

Second, we combine these data with country-level information on average marginal costs abroad from Bankscope, which reduces the panel to 77 countries. There are still 1767 German banks corresponding to 1,080,868 observations in the ijt panel over the years 2002-2012 available. 
Table B.1

Variable definitions.

\begin{tabular}{|c|c|}
\hline Name and Acronym & Source and Definition \\
\hline \multicolumn{2}{|l|}{ Dependent variable } \\
\hline Lending abroad $\left(T_{i j t}\right)$ & AUSTA. $T_{i j t}$ equals 1 when bank $i$ lends through affiliates in country $j$ at time $t$ and 0 otherwise \\
\hline \multicolumn{2}{|l|}{ Cost leadership variables } \\
\hline Bank marginal costs $\left(c_{i t}\right)$ & $\begin{array}{l}\text { BS. German bank marginal costs as computed from a world cost function using stochastic frontier analysis. See } \\
\text { Appendix A }\end{array}$ \\
\hline Marginal costs abroad $\left(c_{j t}\right)$ & $\begin{array}{l}\text { BS. Marginal costs abroad as computed from a world cost function using stochastic frontier analysis } \\
\text { See Appendix A. Marginal costs are averaged in each foreign host country and in each year }\end{array}$ \\
\hline Cost leadership $\left(I\left(c_{i t}<c_{j t}\right)\right)$ & $\begin{array}{l}\text { BS. An indicator variable equal to one whenever parent banks' marginal costs are lower than the marginal cost } \\
\text { of the mean bank in country } j \text { and zero otherwise }\end{array}$ \\
\hline \multicolumn{2}{|l|}{ Parent controls } \\
\hline Return on equity (roe) & BS. Pre-impairment operating profit as a percentage of total equity \\
\hline Z-score $(z s)$ & $\begin{array}{l}\text { BS. Sum of return on assets (RoA) and the capital ratio (Equity/total assets) divided by the standard deviation of } \\
\text { return on assets over the sample period }\end{array}$ \\
\hline Credit risk $(\mathrm{cr})$ & BS. Loan impairment charges as a percentage of gross loans \\
\hline Size quintile $(s q)$ & BS. A quintile indicator based on the distribution of total assets at home in each year to measure bank size \\
\hline \multicolumn{2}{|l|}{ Macro controls } \\
\hline Price of capital abroad $\left(r_{j t}^{*}\right)$ & BS. Foreign bank revenues divided by total assets, averaged in each foreign host country and each year \\
\hline Net interest margin abroad $\left(\operatorname{nim}_{j t}\right)$ & $\begin{array}{l}\text { BS. The difference between interest rate revenue relative to gross loans and interest expenses relative to } \\
\text { customer deposits, averaged in each foreign host country and each year }\end{array}$ \\
\hline Capital stock $\left(K_{j t}\right)$ & PWT. Capital stock at constant 2011 national prices (in trillions 2011 US dollar) \\
\hline Marginal product of capital $\left(M P K_{j t}\right)$ & PWT. Calculated following Caselli and Feyrer (2007), using PWT 9.0 data on labor share, capital stock and GDP \\
\hline Foreign funding share $\left(\alpha_{j t}\right)$ & BIS. Ratio of local currency liabilities on local residents relative to local currency claims on local residents \\
\hline Openness foreign market $\left(\beta_{j t}\right)$ & $\mathrm{CvH}$. Percentage of foreign banks that are active in each foreign country and year \\
\hline
\end{tabular}

Notes: This table defines variables and provides the sources of data. AUSTA, Bundesbank External position of banks data (AUSTA "Auslandsstatus"); BS, Bankscope; PWT, Penn World Tables (PWT 9.0, Feenstra et al., 2015); BIS, Bank for International Settlements; CvH, bank ownership database of Claessens and van Horen (2015).

Table B.2

Summary statistics macro variables $\mathrm{j}$, t dimension.

\begin{tabular}{|c|c|c|c|c|c|c|}
\hline & Mean & SD & p5 & p95 & $\mathrm{N}$ & Countries \\
\hline Marginal costs abroad $\left(c_{2 j}\right)$ & 0.044 & 0.033 & 0.000 & 0.104 & 608 & 75 \\
\hline Price of capital abroad $\left(r_{j t}^{*}\right)$ & 0.076 & 0.036 & 0.038 & 0.140 & 608 & 75 \\
\hline Net interest margin abroad $\left(n_{j t}\right)$ & 0.071 & 0.046 & 0.018 & 0.151 & 605 & 75 \\
\hline Capital Stock $\left(K_{j t}\right)$ & 3.346 & 6.960 & 0.092 & 11.662 & 523 & 61 \\
\hline Marginal productivity of capital $\left(M P K_{j t}\right)$ & 0.153 & 0.070 & 0.083 & 0.277 & 509 & 59 \\
\hline Foreign funding share $\left(\alpha_{j t}\right)$ & 0.233 & 0.352 & -0.398 & 0.694 & 521 & 61 \\
\hline Openness foreign market $\left(\beta_{j t}\right)$ & 0.404 & 0.265 & 0.014 & 0.867 & 523 & 61 \\
\hline
\end{tabular}

Notes: This table reports summary statistics on the macro-economic variables described in the methodology section. SD indicates standard deviation, $\mathrm{N}$ indicates the number of observations, Countries indicates the number of countries, and p5 and p95 are the 5th and 95th percentile, respectively.

Third, we merge these data with bank-level marginal cost estimates, which reduces the sample to 1696 German banks. There are still 77 countries over the years 2002-2012, corresponding to 896,574 observations in the ijt panel.

Fourth, we lag explanatory variables by one year, leading to a sample of 1600 German banks active in 75 countries over the years 2003-2012, as shown in Column (1), (2), (3) and (7) of Table 3.

Finally, the combination with macro control variables reduces the number of countries to 59, see Table 3 . The number of banks remains 1600 with 621,746 corresponding observations in the ijt panel. Table B.1 provides a description of all the variables used in our main estimations. Table B.2 summarizes in the lower panel the data for the unbalanced country-year panel of macro data, which is matched to the foreign affiliate data. In the upper panel, we also show the country level information on foreign average marginal costs, average interest rates, and net interest margins derived from Bankscope data.

\section{Appendix C. Additional tables}

See Tables C.1-C.4. 
Table C.1

Summary statistics control variables in the ijt-dimension according to presence abroad.

\begin{tabular}{|c|c|c|c|c|c|c|c|c|c|c|c|c|}
\hline & \multicolumn{3}{|c|}{ Commercials } & \multicolumn{3}{|c|}{ Savings } & \multicolumn{3}{|c|}{ Cooperatives } & \multicolumn{3}{|c|}{ All } \\
\hline & Mean & $S D$ & $N$ & Mean & $S D$ & $N$ & Mean & $S D$ & $N$ & Mean & $S D$ & $N$ \\
\hline \multicolumn{13}{|l|}{ Non-affiliate } \\
\hline $\begin{array}{c}\text { Price of capital } \\
\text { abroad }\left(r_{j t}^{*}\right)\end{array}$ & 0.076 & 0.037 & 32,781 & 0.076 & 0.037 & 204,687 & 0.075 & 0.036 & 378,805 & 0.075 & 0.036 & 616,273 \\
\hline $\begin{array}{l}\text { Net interest margin } \\
\text { abroad }\left(n_{j t}\right)\end{array}$ & 0.070 & 0.044 & 32,781 & 0.070 & 0.044 & 204,687 & 0.070 & 0.043 & 378,805 & 0.070 & 0.044 & 616,273 \\
\hline $\begin{array}{l}\text { Return on equity } \\
\quad \text { (roe) }\end{array}$ & 14.313 & 13.961 & 32,781 & 17.852 & 6.049 & 204,687 & 15.236 & 5.758 & 378,805 & 16.056 & 6.674 & 616,273 \\
\hline Z-score $(z s)$ & 24.651 & 25.007 & 32,781 & 36.280 & 16.244 & 204,687 & 33.440 & 14.911 & 378,805 & 33.916 & 16.252 & 616,273 \\
\hline Credit risk ( $c r)$ & 0.774 & 1.307 & 32,781 & 0.780 & 0.806 & 204,687 & 0.750 & 0.722 & 378,805 & 0.761 & 0.792 & 616,273 \\
\hline Size quintile $(s q)$ & 3.695 & 1.446 & 32,781 & 4.020 & 1.010 & 204,687 & 2.395 & 1.228 & 378,805 & 3.004 & 1.405 & 616,273 \\
\hline Total Assets (bln) & 14.233 & 59.056 & 32,781 & 3.514 & 15.073 & 204,687 & 0.816 & 4.761 & 378,805 & 2.426 & 16.861 & 616,273 \\
\hline \multicolumn{13}{|l|}{ Affiliate } \\
\hline $\begin{array}{c}\text { Price of capital } \\
\text { abroad }\left(r_{j t}^{*}\right)\end{array}$ & 0.071 & 0.034 & 3274 & 0.070 & 0.035 & 1706 & 0.072 & 0.034 & 493 & 0.071 & 0.035 & 5473 \\
\hline $\begin{array}{l}\text { Net interest margin } \\
\text { abroad }\left(n_{j t}\right)\end{array}$ & 0.072 & 0.046 & 3274 & 0.072 & 0.046 & 1706 & 0.072 & 0.046 & 493 & 0.072 & 0.046 & 5473 \\
\hline $\begin{array}{l}\text { Return on equity } \\
\quad \text { (roe) }\end{array}$ & 10.931 & 12.679 & 3274 & 16.663 & 13.819 & 1706 & 6.679 & 6.011 & 493 & 12.335 & 12.993 & 5473 \\
\hline Z-score $(z s)$ & 15.478 & 12.952 & 3274 & 16.481 & 9.826 & 1706 & 21.671 & 7.057 & 493 & 16.348 & 11.744 & 5473 \\
\hline Credit risk ( $\mathrm{cr}$ ) & 0.584 & 0.854 & 3274 & 0.427 & 0.638 & 1706 & 0.917 & 1.561 & 493 & 0.565 & 0.894 & 5473 \\
\hline Size quintile $(s q)$ & 4.972 & 0.245 & 3274 & 5.000 & 0.000 & 1706 & 4.919 & 0.363 & 493 & 4.976 & 0.220 & 5473 \\
\hline Total Assets (bln) & 377.462 & 523.900 & 3274 & 197.569 & 106.785 & 1706 & 182.895 & 90.578 & 493 & 303.861 & 420.171 & 5473 \\
\hline \multicolumn{13}{|l|}{ All } \\
\hline $\begin{array}{l}\text { Price of capital } \\
\text { abroad }\left(r_{j t}^{*}\right)\end{array}$ & 0.076 & 0.037 & 36,055 & 0.076 & 0.037 & 206,393 & 0.075 & 0.036 & 379,298 & 0.075 & 0.036 & 621,746 \\
\hline $\begin{array}{l}\text { Net interest margin } \\
\text { abroad }\left(n_{j t}\right)\end{array}$ & 0.070 & 0.044 & 36,055 & 0.070 & 0.044 & 206,393 & 0.070 & 0.043 & 379,298 & 0.070 & 0.044 & 621,746 \\
\hline $\begin{array}{l}\text { Return on equity } \\
\quad \text { (roe) }\end{array}$ & 14.006 & 13.883 & 36,055 & 17.842 & 6.154 & 206,393 & 15.225 & 5.767 & 379,298 & 16.023 & 6.765 & 621,746 \\
\hline Z-score $(z s)$ & 23.818 & 24.305 & 36,055 & 36.116 & 16.300 & 206,393 & 33.425 & 14.909 & 379,298 & 33.761 & 16.300 & 621,746 \\
\hline Credit risk $(\mathrm{cr})$ & 0.757 & 1.274 & 36,055 & 0.778 & 0.806 & 206,393 & 0.750 & 0.724 & 379,298 & 0.759 & 0.793 & 621,746 \\
\hline Size quintile $(s q)$ & 3.811 & 1.429 & 36,055 & 4.028 & 1.010 & 206,393 & 2.398 & 1.231 & 379,298 & 3.021 & 1.411 & 621,746 \\
\hline Total Assets (bln) & 47.216 & 197.435 & 36,055 & 5.118 & 25.064 & 206,393 & 1.053 & 8.736 & 379,298 & 5.079 & 51.268 & 621,746 \\
\hline
\end{tabular}

Notes: This table reports summary statistics for the bank-level control variables per banking group. Each group includes large and regional banks. SD indicates standard deviation, $N$ indicates the number of observations. All marginal costs follow from the sum of the derivatives of the cost function w.r.t to outputs $y_{1}, y_{2}$, and $y_{3}$. We take the mean of the distribution of prices and costs in each host country $i$ at time $t$ or in Germany at time $t$.

Table C.2

Alternative estimators for a sparsely specified model.

\begin{tabular}{|c|c|c|c|c|}
\hline & OLS & Probit & Logit & cloglog \\
\hline Bank marginal costs $\left(c_{i t}\right)$ & $\begin{array}{l}-0.1882^{* * *} \\
{[0.012]}\end{array}$ & $\begin{array}{l}-0.1010^{* * *} \\
{[0.011]}\end{array}$ & $\begin{array}{l}-0.0917^{* * *} \\
{[0.010]}\end{array}$ & $\begin{array}{l}-0.0881^{* * *} \\
{[0.010]}\end{array}$ \\
\hline Marginal costs abroad $\left(c_{j t}\right)$ & $\begin{array}{l}-0.0419^{* * *} \\
{[0.008]}\end{array}$ & $\begin{array}{l}-0.0216^{* * *} \\
{[0.008]}\end{array}$ & $\begin{array}{l}-0.0153^{* *} \\
{[0.008]}\end{array}$ & $\begin{array}{l}-0.0134^{*} \\
{[0.008]}\end{array}$ \\
\hline Cost leadership $\left(I\left(c_{i t}<c_{j t}\right)\right)$ & $\begin{array}{l}0.0060^{* * *} \\
{[0.001]}\end{array}$ & $\begin{array}{l}0.0034^{* * *} \\
{[0.001]}\end{array}$ & $\begin{array}{l}0.0023^{* * *} \\
{[0.001]}\end{array}$ & $\begin{array}{l}0.0020^{* * *} \\
{[0.001]}\end{array}$ \\
\hline Price of capital abroad $\left(r_{j t}^{*}\right)$ & $\begin{array}{l}0.0041 \\
{[0.007]}\end{array}$ & $\begin{array}{l}0.0019 \\
{[0.006]}\end{array}$ & $\begin{array}{l}0.0019 \\
{[0.005]}\end{array}$ & $\begin{array}{l}0.0015 \\
{[0.005]}\end{array}$ \\
\hline Net interest margin abroad $\left(n_{j t}\right)$ & $\begin{array}{l}-0.0005 \\
{[0.007]}\end{array}$ & $\begin{array}{l}-0.0021 \\
{[0.005]}\end{array}$ & $\begin{array}{l}-0.0025 \\
{[0.005]}\end{array}$ & $\begin{array}{l}-0.0026 \\
{[0.005]}\end{array}$ \\
\hline Capital stock $\left(K_{j t}\right)$ & $\begin{array}{l}-0.0004 \\
{[0.000]}\end{array}$ & $\begin{array}{l}-0.0003^{*} \\
{[0.000]}\end{array}$ & $\begin{array}{l}-0.0003^{* *} \\
{[0.000]}\end{array}$ & $\begin{array}{l}-0.0003^{* *} \\
{[0.000]}\end{array}$ \\
\hline Marginal product of capital $\left(M P K_{j t}\right)$ & $\begin{array}{l}0.0047 \\
{[0.005]}\end{array}$ & $\begin{array}{l}0.0071 \\
{[0.007]}\end{array}$ & $\begin{array}{l}0.0083 \\
{[0.007]}\end{array}$ & $\begin{array}{l}0.0085 \\
{[0.007]}\end{array}$ \\
\hline Foreign funding share $\left(\alpha_{j t}\right)$ & $\begin{array}{l}0.0001 \\
{[0.000]}\end{array}$ & $\begin{array}{l}-0.0001 \\
{[0.000]}\end{array}$ & $\begin{array}{l}-0.0001 \\
{[0.000]}\end{array}$ & $\begin{array}{l}-0.0000 \\
{[0.000]}\end{array}$ \\
\hline Openness foreign market $\left(\beta_{j t}\right)$ & $\begin{array}{l}-0.0044 \\
{[0.003]}\end{array}$ & $\begin{array}{l}-0.0008 \\
{[0.003]}\end{array}$ & $\begin{array}{l}-0.0019 \\
{[0.003]}\end{array}$ & $\begin{array}{l}-0.0018 \\
{[0.003]}\end{array}$ \\
\hline Observations & 621,746 & 621,746 & 621,746 & 621,746 \\
\hline Estimator & OLS & probit & logit & cloglog \\
\hline Observations non-zero & 5473 & 5473 & 5473 & 5473 \\
\hline Number of banks & 1600 & 1600 & 1600 & 1600 \\
\hline
\end{tabular}


Table C.2 (continued)

\begin{tabular}{|c|c|c|c|c|}
\hline & OLS & Probit & Logit & cloglog \\
\hline Number of countries & 59 & 59 & 59 & 59 \\
\hline Log-likelihood & & $-23,476$ & $-23,499$ & $-23,513$ \\
\hline AIC & & 0.0757 & 0.0758 & 0.0759 \\
\hline
\end{tabular}

Notes: This table reports the marginal effects of estimating the regression model in Eq. (1) for the years 2003-2012 for different estimators. The dependent variable is an indicator equal to one if bank $i$ lends to country $j$ through an affiliate at time $t$. All explanatory variables are lagged by one period. All estimations include year fixed effects, country fixed effects, and banking group fixed effects. Standard errors are clustered at the country level and are reported in brackets. ${ }^{* * *} \mathrm{p}<.01,{ }^{* *} \mathrm{p}<.05,{ }^{*} \mathrm{p}<.1$.

Table C.3

Controlling for alternative size proxies.

\begin{tabular}{|c|c|c|c|c|}
\hline & (1) & (2) & (3) & (4) \\
\hline Bank marginal costs $\left(c_{i t}\right)$ & $\begin{array}{l}-0.0557^{\text {**** }} \\
{[0.009]}\end{array}$ & $\begin{array}{l}-0.0835^{* * *} \\
{[0.009]}\end{array}$ & $\begin{array}{l}-0.0627^{* * *} \\
{[0.008]}\end{array}$ & $\begin{array}{l}-0.0464^{* * *} \\
{[0.008]}\end{array}$ \\
\hline Marginal costs abroad $\left(c_{j t}\right)$ & $\begin{array}{l}-0.0059 \\
{[0.007]}\end{array}$ & $\begin{array}{l}-0.0119 \\
{[0.008]}\end{array}$ & $\begin{array}{l}-0.0187^{* *} \\
{[0.008]}\end{array}$ & $\begin{array}{l}-0.0123^{*} \\
{[0.007]}\end{array}$ \\
\hline Cost leadership $\left(I\left(c_{i t}<c_{j t}\right)\right)$ & $\begin{array}{l}0.0004 \\
{[0.000]}\end{array}$ & $\begin{array}{l}0.0012^{* * *} \\
{[0.000]}\end{array}$ & $\begin{array}{l}0.0020^{* * * *} \\
{[0.000]}\end{array}$ & $\begin{array}{l}0.0014^{* * *} \\
{[0.000]}\end{array}$ \\
\hline Return on equity (roe) & $\begin{array}{l}-0.0001^{* * *} \\
{[0.000]}\end{array}$ & $\begin{array}{l}-0.0001^{* * *} \\
{[0.000]}\end{array}$ & $\begin{array}{l}-0.0001^{* * *} \\
{[0.000]}\end{array}$ & $\begin{array}{l}-0.0002^{* * *} \\
{[0.000]}\end{array}$ \\
\hline Z-score $(z s)$ & $\begin{array}{l}-0.0001^{* * *} \\
{[0.000]}\end{array}$ & $\begin{array}{l}-0.0002^{* * *} \\
{[0.000]}\end{array}$ & $\begin{array}{l}-0.0003^{* * *} \\
{[0.000]}\end{array}$ & $\begin{array}{l}-0.0002^{* * *} \\
{[0.000]}\end{array}$ \\
\hline Credit risk (cr) & $\begin{array}{l}-0.0002^{*} \\
{[0.000]}\end{array}$ & $\begin{array}{l}-0.0003^{* *} \\
{[0.000]}\end{array}$ & $\begin{array}{l}-0.0001 \\
{[0.000]}\end{array}$ & $\begin{array}{l}0.0002^{*} \\
{[0.000]}\end{array}$ \\
\hline Price of capital abroad $\left(r_{j t}^{*}\right)$ & $\begin{array}{l}0.0059 \\
{[0.006]}\end{array}$ & $\begin{array}{l}0.0042 \\
{[0.006]}\end{array}$ & $\begin{array}{l}0.0023 \\
{[0.006]}\end{array}$ & $\begin{array}{l}0.0031 \\
{[0.005]}\end{array}$ \\
\hline Net interest margin abroad $\left(n_{j t}\right)$ & $\begin{array}{l}-0.0030 \\
{[0.003]}\end{array}$ & $\begin{array}{l}-0.0044 \\
{[0.005]}\end{array}$ & $\begin{array}{l}-0.0045 \\
{[0.005]}\end{array}$ & $\begin{array}{l}-0.0029 \\
{[0.004]}\end{array}$ \\
\hline Capital stock $\left(K_{j t}\right)$ & $\begin{array}{l}0.0000 \\
{[0.000]}\end{array}$ & $\begin{array}{l}-0.0000 \\
{[0.000]}\end{array}$ & $\begin{array}{l}-0.0003^{* *} \\
{[0.000]}\end{array}$ & $\begin{array}{l}-0.0001 \\
{[0.000]}\end{array}$ \\
\hline Marginal product of capital $\left(M P K_{j t}\right)$ & $\begin{array}{l}0.0056 \\
{[0.005]}\end{array}$ & $\begin{array}{l}0.0081 \\
{[0.006]}\end{array}$ & $\begin{array}{l}0.0106 \\
{[0.007]}\end{array}$ & $\begin{array}{l}0.0079 \\
{[0.006]}\end{array}$ \\
\hline Foreign funding share $\left(\alpha_{j t}\right)$ & $\begin{array}{l}-0.0005 \\
{[0.000]}\end{array}$ & $\begin{array}{l}0.0000 \\
{[0.000]}\end{array}$ & $\begin{array}{l}0.0000 \\
{[0.000]}\end{array}$ & $\begin{array}{l}-0.0002 \\
{[0.000]}\end{array}$ \\
\hline Openness foreign market $\left(\beta_{j t}\right)$ & $\begin{array}{l}-0.0107^{* * *} \\
{[0.003]}\end{array}$ & $\begin{array}{l}-0.0081^{* *} \\
{[0.003]}\end{array}$ & $\begin{array}{l}0.0001 \\
{[0.003]}\end{array}$ & $\begin{array}{l}-0.0026 \\
{[0.003]}\end{array}$ \\
\hline Total assets in billions & $\begin{array}{l}0.1578^{* * *} \\
{[0.003]}\end{array}$ & & & \\
\hline Loans in billions & & $\begin{array}{l}0.3920^{* * *} \\
{[0.005]}\end{array}$ & & \\
\hline Fixed assets in billions & & & $\begin{array}{l}0.1086^{* * *} \\
{[0.001]}\end{array}$ & \\
\hline Number of employees in thousands & & & & $\begin{array}{l}0.0057^{* * *} \\
{[0.000]}\end{array}$ \\
\hline Observations & 621,746 & 621,746 & 621,746 & 621,746 \\
\hline Observations non-zero & 5473 & 5473 & 5473 & 5473 \\
\hline Pseudo R-squared & 0.628 & 0.577 & 0.509 & 0.577 \\
\hline Number of banks & 1600 & 1600 & 1600 & 1600 \\
\hline Number of countries & 59 & 59 & 59 & 59 \\
\hline
\end{tabular}

Notes: This table reports the marginal effects of estimating the cloglog model in Eq. (1) for the years 2003-2012. The dependent variable is an indicator equal to one if bank $i$ lends to country $j$ through an affiliate at time $t$. All explanatory variables are lagged by one period. Size proxies are winsorized by setting the 10 largest observations equal to the 11th largest observation in each year. We include but do not report country, year, and banking group fixed effects. Standard errors are clustered at the country level and are reported in brackets. ${ }^{* * *} \mathrm{p}<.01,{ }^{* *} \mathrm{p}<.05,{ }^{*} \mathrm{p}<.1$.

Table C.4

Excluding the largest countries and banks.

\begin{tabular}{lllll}
\hline & \multicolumn{1}{c}{$(1)$} & \multicolumn{1}{c}{$(2)$} & \multicolumn{1}{c}{$(3)$} \\
\hline Bank marginal costs $\left(c_{i t}\right)$ & $-0.0505^{* * *}$ & 0.0021 & $-0.0512^{* * *}$ & $-0.0485^{* * *}$ \\
& {$[0.010]$} & {$[0.006]$} & {$[0.010]$} & {$[0.010]$} \\
Marginal costs abroad $\left(c_{j t}\right)$ & $-0.0100^{* *}$ & -0.0035 & -0.0109 & -0.0069 \\
Cost leadership $\left(I\left(c_{i t}<c_{j t}\right)\right)$ & {$[0.005]$} & {$[0.005]$} & {$[0.007]$} & $0.0014^{* *}$ \\
& $0.0014^{* * *}$ & $0.0012^{* * *}$ & {$[0.001]$} & $0.0014^{* * *}$
\end{tabular}


Table C.4 (continued)

\begin{tabular}{|c|c|c|c|c|}
\hline & $(1)$ & $(2)$ & $(3)$ & $(4)$ \\
\hline Return on equity (roe) & $\begin{array}{l}-0.0001^{* * *} \\
{[0.000]}\end{array}$ & $\begin{array}{l}-0.0001^{* * *} \\
{[0.000]}\end{array}$ & $\begin{array}{l}-0.0001^{* * *} \\
{[0.000]}\end{array}$ & $\begin{array}{l}-0.0001^{* * *} \\
{[0.000]}\end{array}$ \\
\hline Z-score $(z s)$ & $\begin{array}{l}-0.0005^{\text {**** }} \\
{[0.000]}\end{array}$ & $\begin{array}{l}-0.0004^{* * *} \\
{[0.000]}\end{array}$ & $\begin{array}{l}-0.0005^{* * *} \\
{[0.000]}\end{array}$ & $\begin{array}{l}-0.0005^{* * *} \\
{[0.000]}\end{array}$ \\
\hline Credit risk $(\mathrm{cr})$ & $\begin{array}{l}-0.0002 \\
{[0.000]}\end{array}$ & $\begin{array}{l}-0.0006^{* * *} \\
{[0.000]}\end{array}$ & $\begin{array}{l}-0.0002^{*} \\
{[0.000]}\end{array}$ & $\begin{array}{l}-0.0001 \\
{[0.000]}\end{array}$ \\
\hline Size quintile $(s q)$ & $\begin{array}{l}0.0181^{* * *} \\
{[0.002]}\end{array}$ & $\begin{array}{l}0.0161^{* * *} \\
{[0.001]}\end{array}$ & $\begin{array}{l}0.0225^{* * *} \\
{[0.003]}\end{array}$ & $\begin{array}{l}0.0176^{* * * *} \\
{[0.002]}\end{array}$ \\
\hline Price of capital abroad $\left(r_{j t}^{*}\right)$ & $\begin{array}{l}0.0068^{*} \\
{[0.004]}\end{array}$ & $\begin{array}{l}-0.0042 \\
{[0.005]}\end{array}$ & $\begin{array}{l}0.0031 \\
{[0.004]}\end{array}$ & $\begin{array}{l}0.0027 \\
{[0.004]}\end{array}$ \\
\hline Net interest margin abroad $\left(n_{j t}\right)$ & $\begin{array}{l}0.0019 \\
{[0.004]}\end{array}$ & $\begin{array}{l}0.0007 \\
{[0.004]}\end{array}$ & $\begin{array}{l}-0.0063^{* * *} \\
{[0.002]}\end{array}$ & $\begin{array}{l}-0.0014 \\
{[0.004]}\end{array}$ \\
\hline Capital stock $\left(K_{j t}\right)$ & $\begin{array}{l}0.0000 \\
{[0.000]}\end{array}$ & $\begin{array}{l}-0.0004^{* * *} \\
{[0.000]}\end{array}$ & $\begin{array}{l}0.0011 \\
{[0.001]}\end{array}$ & $\begin{array}{l}-0.0001 \\
{[0.000]}\end{array}$ \\
\hline Marginal product of capital $\left(M P K_{j t}\right)$ & $\begin{array}{l}0.0025 \\
{[0.006]}\end{array}$ & $\begin{array}{l}0.0083 \\
{[0.008]}\end{array}$ & $\begin{array}{l}0.0052 \\
{[0.005]}\end{array}$ & $\begin{array}{l}0.0071 \\
{[0.006]}\end{array}$ \\
\hline Foreign funding share $\left(\alpha_{j t}\right)$ & $\begin{array}{l}-0.0006^{*} \\
{[0.000]}\end{array}$ & $\begin{array}{l}0.0002 \\
{[0.000]}\end{array}$ & $\begin{array}{l}-0.0001 \\
{[0.000]}\end{array}$ & $\begin{array}{l}-0.0007^{* *} \\
{[0.000]}\end{array}$ \\
\hline Openness foreign market $\left(\beta_{j t}\right)$ & $\begin{array}{l}0.0007 \\
{[0.002]}\end{array}$ & $\begin{array}{l}0.0042 \\
{[0.003]}\end{array}$ & $\begin{array}{l}0.0001 \\
{[0.003]}\end{array}$ & $\begin{array}{l}-0.0005 \\
{[0.002]}\end{array}$ \\
\hline Observations & 381,758 & 619,484 & 390,567 & 385,081 \\
\hline Observations non-zero & 2253 & 3589 & 2524 & 2273 \\
\hline Pseudo R-squared & 0.453 & 0.398 & 0.465 & 0.452 \\
\hline Number of banks & 1600 & 1595 & 1600 & 1600 \\
\hline Number of countries & 39 & 59 & 39 & 39 \\
\hline
\end{tabular}

Notes: This table reports the marginal effects of estimating the cloglog model in Eq. (1) for the years 2003-2012. The dependent variable is an indicator equal to one if bank $i$ lends to country $j$ through an affiliate at time $t$. All explanatory variables are lagged by one period. Column (1) excludes the 20 largest countries in terms of German banks' total loans. Column (2) excludes the 5 largest banks based on median total assets over the sample period. Column (3) excludes the 20 largest countries in terms of median GDP in constant 2005 prices over the sample period. Column (4) excludes the 20 largest countries in terms of median GDP per capita in constant 2005 prices over the sample period. We include but do not report country, year, and banking group fixed effects. Standard errors are clustered at the country level and are reported in brackets. ${ }^{* * *} \mathrm{p}<.01,{ }^{* *} \mathrm{p}<.05,{ }^{*} \mathrm{p}<.1$.

\section{References}

Aviat, A., Coeurdacier, N., 2007. The geography of trade in goods and asset holdings. J. Int. Econ. 71, 22-51.

Baetschmann, G., Winkelmann, R., 2013. Modelling zero-inflated count data when exposure varies: with an application to tumor counts. Biometr. J. 55, 679686.

Beck, T., Demirgüç-Kunt, A., Levine, R., 2009. Financial Institutions and Markets Across Countries and Over Time-data and Analysis. The World Bank Policy Research Working Paper 4943.

Berger, A.N., 2007. Obstacles to a global banking system: old Europe versus new Europe. J. Bank. Finan. 31, 1955-1973.

Berger, A.N., Humphrey, D.B., 1997. Efficiency of financial institutions: international survey and directions for future research. Eur. J. Oper. Res. 98 (2), 175212.

Bernard, A.B., Eaton, J., Jensen, J.B., Kortum, S., 2003. Plants and productivity in international trade. Am. Econ. Rev. 93, 1268-1290.

Breinlich, H., Criscuolo, C., 2011. International trade in services: a portrait of importers and exporters. J. Int. Econ. 84, $188-206$.

Bruno, V., Hauswald, R., 2014. The real effect of foreign banks. Rev. Finan. 18, 1683-1716.

Buch, C.M., 2000. Why do banks go abroad? Evidence from German data. Financ. Markets, Inst. Instrum. 9, $33-67$.

Buch, C.M., Koch, C.T., Koetter, M., 2011. Size, productivity, and international banking. J. Int. Econ. 85, 329-334.

Buch, C.M., Koch, C.T., Koetter, M., 2013. Do banks benefit from internationalization? Revisiting the market power-risk nexus. Rev. Finan. 17, $1401-1435$.

Buch, C.M., Koch, C.T., Koetter, M., 2014. Should I stay or should I go? Bank productivity and internationalization decisions. J. Bank. Finan. 42, $266-282$.

Buch, C.M., 2003. Information or regulation: What drives the international activities of commercial banks? J. Money, Credit, Bank. 35, 851-869.

Caselli, F., Feyrer, J., 2007. The marginal product of capital. Quart. J. Econ. 122, 535-568.

Cerutti, E., Dell?Ariccia, G., Martínez Pería, M., 2007. How banks go abroad: Branches or subsidiaries? J. Bank. Finan. $31,1669-1692$.

Cetorelli, N., Goldberg, L., 2012a. Banking globalization and monetary transmission. J. Finan. 67, 1811-1843.

Cetorelli, N., Goldberg, L., 2012b. Liquidity Management of U.S. Global banks: internal capital markets in the Great Recession. J. Int. Econ. 88, $299-311$.

Claessens, S., van Horen, N., 2014a. Foreign banks: trends and impact. J. Money, Credit, Bank. 46, $295-326$.

Claessens, S., van Horen, N., 2014b. Location decisions of foreign banks and competitor remoteness. J. Money, Credit, Bank. 46, 145-170.

Claessens, S., van Horen, N., 2015. The impact of the global financial crisis on banking globalization. IMF Econ. Rev. 64, 868-918.

De Blas, B., Russ, K., 2013. All banks great, small, and global: loan pricing and foreign competition. Int. Rev. Econ. Finan. $26,4-24$.

De Haas, R., van Horen, N., 2013. Running for the exit: international bank lending during a financial crisis. Rev. Financ. Stud. $26,244-285$.

De Haas, R.T., Van Lelyveld, I.P., 2010. Internal capital markets and lending by multinational bank subsidiaries. J. Financ. Intermed. $19,1-25$.

De Haas, R.T., Van Lelyveld, I.P., 2014. Multinational banks and the global financial crisis: Weathering the perfect storm? J. Money, Credit, Bank. 46, 333-364.

Delis, M.D., 2012. Bank competition, financial reform, and institutions: the importance of being developed. J. Dev. Econ. $97,450-465$.

Deutsche Bundesbank, 2013. Bankenstatistik - Statistisches Beiheft 1 zum Monatsbericht. Frankfurt am Main.

Deutsche Bundesbank, 2016. Bankenstatistik: Statistisches Beiheft 1 zum Monatsbericht. Frankfurt am Main.

Eichler, S., Littke, H.C.N., Tonzer, L., 2017. Central bank transparency and cross-border banking. J. Int. Money Finan. 74, 1-30.

European Central Bank, 2016. Financial Integration in Europe, Chapter Special Feature B: National Options and Discretions in the Prudential Regulatory Framework for Banks. Frankfurt am Main: European, pp. 99-115.

European Commission, 2012. State aid: Commission Approves Restructuring Aid to BayernLB Subject to Repayment of 5 billion Euro of Aid. Press release, European Commission. 
Feenstra, R.C., Inklaar, R., Timmer, M.P., 2015. The next generation of the Penn World Table. Am. Econ. Rev. 105, 3150-3182.

Fiechter, J., Ötker Robe, I., Ilyina, A., Hsu, A., Santos, Michael, Surti, J., 2011. Subsidiaries or Branches: Does One Size Fit All? IMF Staff Discussion Note 4. Fiorentino, E., Koch, C., Rudek, W., 2010. Microdatabase: External Position Reports of German banks. Frankfurt a.M.: Deutsche Bundesbank.

Focarelli, D., Pozzolo, A., 2005. Where do banks expand abroad? An empirical analysis. J. Bus. 78, 2435-2465.

Frey, R., Kerl, C., 2015. Multinational banks in the crisis: foreign affiliate lending as a mirror of funding pressure and competition on the internal capital market. J. Bank. Finan. 50, 52-68.

Galema, R., Koetter, M., Liesegang, C., 2016. Lend global, fund local? Price and funding cost margins in multinational banking. Rev. Finan. 20, 1981-2014. German Council of Economic Experts, 2013. Annual Economic Report 2013/14: “Against a backward-looking economic policy”. Wiesbaden: German Council of Economic Experts.

Giannetti, M., Laeven, L., 2012. The flight home effect: evidence from the syndicated loan market during financial crises. J. Financ. Econ. 104, 23-43.

Giannetti, M., Ongena, S., 2012. Lending by example: direct and indirect effects of foreign banks in emerging markets. J. Int. Econ. 86, 167-180.

Helpman, E., 2006. Trade, FDI, and the Organization of Firms. NBER Working Paper 12091.

Helpman, E., Melitz, M., Yeaple, S., 2004. Exports versus FDI with heterogeneous firms. Am. Econ. Rev. 94, 300-316.

Kerl, C., Koch, C., 2015. International banking and liquidity transmission: lessons from Germany. IMF Econ. Rev. 63, 496-514.

Kick, T., Koetter, M., Storz, M., 2016. Cross-border Transmission of Emergency Liquidity. Deutsche Bundesbank Discussion Paper 34

King, G., Zeng, L., 2001. Logistic regression in rare events data. Polit. Anal., 137-163

Koetter, M., Kolari, J., Spierdijk, L., 2012. Enjoying the quiet life under deregulation? Evidence from adjusted Lerner indices for U.S. banks. Rev. Econ. Stat. 94, $462-480$.

Laeven, L., Levine, R., 2009. Bank governance, regulation, and risk taking. J. Financ. Econ. 93, $259-275$.

Maaß, S., 2007. Die Haspa wird im Ausland aktiver. Die Welt.

Melitz, M., 2003. The impact of trade on intra-industry reallocations and aggregate industry productivity. Econometrica $71,1695-1725$.

Melitz, M.J., Ottaviano, G.I., 2008. Market size, trade, and productivity. Rev. Econ. Stud. 75, 295-316.

Mester, L., 1996. A study of bank efficiency taking into account risk-preferences. J. Bank. Finan. 20, 1025-1045.

Niepmann, F., 2015. Banking across borders. J. Int. Econ. 96, 244-265.

Niepmann, F., 2016. Banking Across Borders with Heterogeneous Banks. International Finance Discussion Papers 1177.

Ongena, S., Popov, A., Udell, G.F., 2012. When the cat's away the mice will play: Does regulation at home affect bank risk-taking abroad? J. Financ. Econ. 108, 727-750.

Sealey, C.W., Lindley, J.T., 1977. Inputs, outputs, and a theory of production and cost and depository financial institutions. J. Finan. 32, $1251-1265$.

von Peter, G., 2017. The Distance Effect in Banking and Trade. mimeo.

Winkelmann, R., Staub, K., 2013. Consistent estimation of zero inflated count data models. Health Econ. 22, $673-686$.

WTO, 2009. International Trade Statistics 2009. World Trade Organization, Geneva.

WTO, 2011. International Trade Statistics 2011. World Trade Organization, Geneva.

WTO, 2015. International Trade Statistics 2015. World Trade Organization, Geneva. 